Florida International University FIU Digital Commons

6-30-2014

\title{
Environmental Performance of Multinationals: A Comparative Study Based On Climate Change Strategy
}

Santhosh Narayanan

snara008@fiu.edu

DOI: $10.25148 /$ etd.FI14071142

Follow this and additional works at: https://digitalcommons.fiu.edu/etd

\section{Recommended Citation}

Narayanan, Santhosh, "Environmental Performance of Multinationals: A Comparative Study Based On Climate Change Strategy" (2014). FIU Electronic Theses and Dissertations. 1518.

https://digitalcommons.fiu.edu/etd/1518 


\title{
FLORIDA INTERNATIONAL UNIVERSITY
}

Miami, Florida

ENVIRONMENTAL PERFORMANCE OF MULTINATIONALS: A COMPARATIVE STUDY BASED ON CLIMATE CHANGE STRATEGY

\author{
A dissertation submitted in partial fulfillment of \\ the requirements for the degree of \\ DOCTOR OF PHILOSOPHY \\ in \\ BUSINESS ADMINSTRATION \\ by \\ Santhosh Narayanan
}

2014 
To: Dean David R. Klock

College of Business Administration

This dissertation, written by Santhosh Narayanan, and entitled Environmental Performance of Multinationals: A Comparative Study Based on Climate Change Strategy, having been approved in respect to style and intellectual content, is referred to you for judgment.

We have read this dissertation and recommend that it be approved.

$\begin{array}{r}\text { Florence George } \\ \hline \text { Ronaldo Parente } \\ \hline \text { Karen Paul } \\ \hline \text { Sumit Kundu, Major Professor }\end{array}$

Date of Defense: June 30, 2014

The dissertation of Santhosh Narayanan is approved.

Dean David R. Klock
College of Business Administration

Florida International University, 2014 


\section{DEDICATION}

Dedicated to Ms. Rajini Menon, the divine that she is. She is not only my mother, father, brother, sister, friend, but also my guide. But for her blessings I would never have been able to complete my Ph.D. and I wish to thank her with all the gratitude for all the blessings I received from her. As a mark of respect and gratitude I surrender the Ph.D. degree that is being conferred upon me at her lotus feet. 


\section{ACKNOWLEDGMENTS}

I would like to express my thanks to all the good hearted, knowledgeable, and creative people in the department for their support during the doctoral program. I am extremely fortunate to interact with and learn from all these wonderful people.

I would like to specially thank my dissertation committee. Dr. Sumit Kundu’s constant guidance, inspiration and generous support throughout the doctoral program were instrumental in shaping me into a successful professional. Dr. Karen Paul's inputs and guidance were very valuable. Dr. Ronaldo Parente’s support, feedback and empathy are acknowledged. Dr. Florence George inputs on statistical methods have helped a lot. I

deeply thank friends in the doctoral program who have helped me both professionally and personally during this journey. 


\title{
ABSTRACT OF THE DISSERTATION \\ ENVIRONMENTAL PERFORMANCE OF MULTINATIONALS: A COMPARATIVE STUDY BASED ON CLIMATE CHANGE STRATEGY
}

\author{
by
}

Santhosh Narayanan

Florida International University, 2014

Miami, Florida

Professor Sumit Kundu, Major Professor

In the context of distinctive international business phenomena of global environmental concern i.e., climate change, this dissertation addresses two research questions. Does multinational enterprise (MNE) orientation (global- or regionalorientation) have an influence on the carbon performance of the multinational? Is there any significant home country effect that drives carbon performance?

Stakeholders are increasingly watching the green performance of the firms and investors are looking for information of how firms deal with externalities such as carbon emission. Environmental capabilities are increasingly becoming the core competence of a multinational enterprise. This also enables the MNE to be an active entity and play a key role in global environmental governance. Defining carbon performance as the capability of firms to integrate climate change strategy into the overall strategy, this dissertation used resource-based view and institutional theory as the theoretical framework along with the concept of regionalization of firms. We argue that differences in integrating strategy to reduce carbon emission (carbon performance) are related to MNE orientation and home country effect. Using a sample of 324 firm-years drawn from the carbon disclosure 
project reports 2011, 2012, and 2013, we analyzed the data running a logistic regression. We found that global-oriented MNEs had better carbon performance compared with regional-oriented MNEs $(\mathrm{p}<0.05)$. We also found home country effect to predict carbon performance of the MNE $(\mathrm{p}<0.10)$. Further, MNEs in environmentally non-sensitive industries were likely to have better carbon performance regardless of whether they are global-oriented or regional-oriented. This result was against the hypothesized relationship. One of the reasons for this result could be projected good image by the firms in environmentally non-sensitive industries because of cost advantage. Lower environmental institutional distance between home and host country of a firm increased the likelihood of its carbon performance regardless of its orientation as global or regional $(\mathrm{p}<0.05)$. We found the climate strategy as dynamic and rapidly evolving. Since the regulatory requirements are expected to be stricter in the near future, the role of business in climate strategy and carbon governance should be comprehensively studied further with clear measurement parameters. 
CHAPTER

PAGE

CHAPTER I:

INTRODUCTION 1

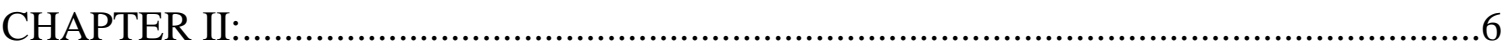

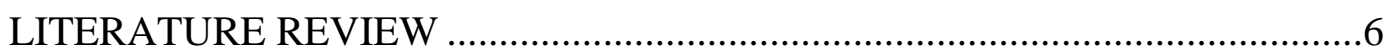

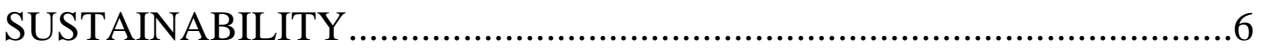

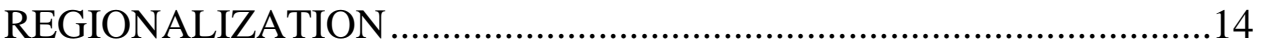

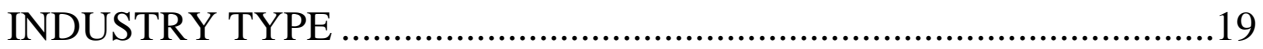

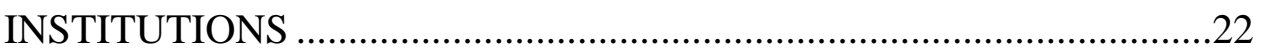

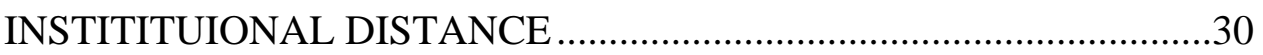

CARBON DISCLOSURE PROJECT …………………….......................34

RESOURCE BASED VIEW ................................................................39

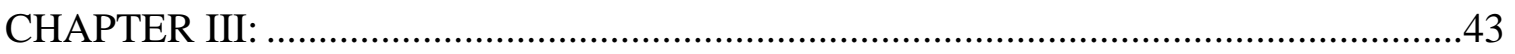

THEORETICAL DEVELOPMENT AND HYPOTHESES .................................43

CHAPTER IV:

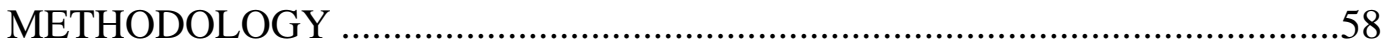

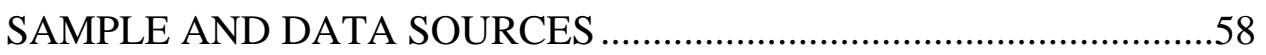

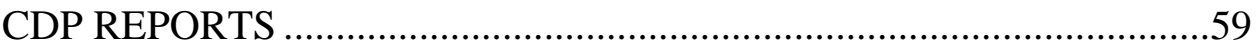

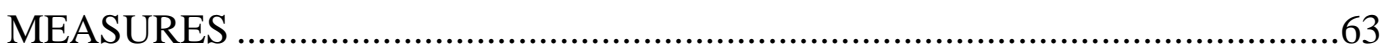

DEPENDENT VARIABLE: CARBON PERFORMANCE .......................63

INDEPENDENT VARIABLE: MNE ORIENTATION ............................65

INDEPENDENT VARIABLE: EUROPEAN OR US MNE.......................66

INDEPENDENT VARIABLE: INDUSTRY TYPE ...................................66

INDEPENDENT VARIABLE: ENVIRONMENTAL

INSTITUTIONAL DISTANCE ……………………….....................66

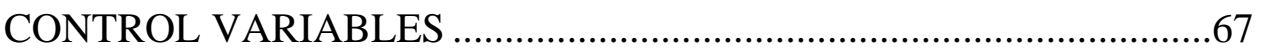

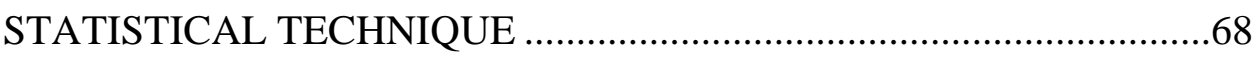

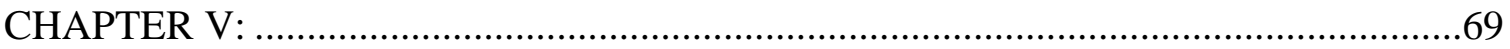

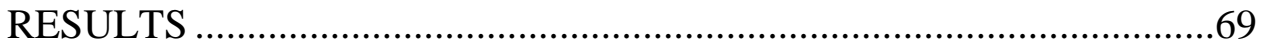

CHAPTER VI: ...

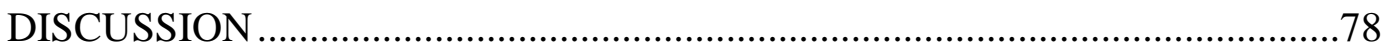

LIMITATIONS AND FUTURE RESEARCH.................................................85

CONCLUSION AND IMPLICATIONS ..........................................................89

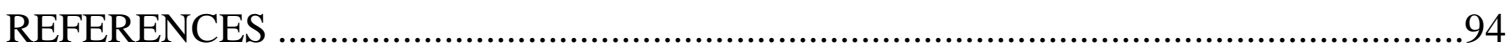

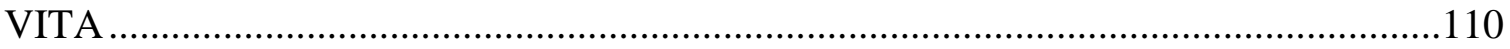




\section{LIST OF TABLES}

TABLE

PAGE

TABLE 1: Industry wise total number of firms participated in the CDP

TABLE 2: Proportion of firms in each performance categories (A to E)........................60

TABLE 3: Industry wise, firms under different carbon performance categories ..............61

TABLE 4: Industry wise, firms under different carbon performance categories (2013)...62

TABLE 5: Performance of firms as a proportion to the total firms................................63

TABLE 6: 2 x 2 matrix of MNE orientation and carbon performance...........................69

TABLE 7: High and low performers - Industry wise distribution................................70

TABLE 8: Performance distribution of European and US multinationals ......................72

TABLE 9: Sample of European and US multinationals used for the analysis .................73

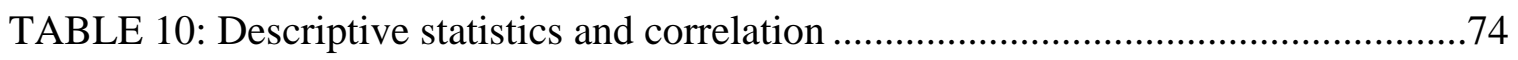

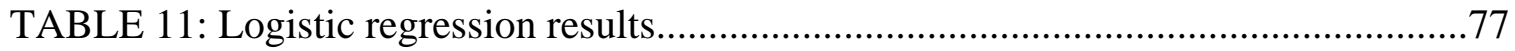




\section{CHAPTER I INTRODUCTION}

"Business is seen as a part of both the problem and the solution; international climate change policies must therefore encourage businesses to make a more positive contribution” (World Investment Report, 2010: 100). This concern is reflected recently from two different but important sectors. First, the CEO of Unilever put forth that deforestation accounting for 15\% of global warming will affect business models of companies, risk the society at large, and lead boycotts by consumers (Polman, 2014). Second, the Obama administration estimates the losses to the U.S. economy on account of climate and weather loss as $\$ 100$ billion for the year 2012 and is in the process of framing new rules to combat climate change. The Environmental Protection Agency (EPA) on June 2, 2014 unveiled a plan to limit carbon emissions from power plants (Whitehouse website, 2014; Bloomberg, 2014). With a huge potential for savings, for U.S. consumers and businesses, of around $\$ 464$ billion by 2030 (Cleetus et al, 2009), the climate change movement is considered to be a global social movement forcing changes in business practices (Reid and Toffel, 2009). The increasing attention of firms, investors and other stakeholders on socially responsible activities is also reflected in the fact that a group of 722 institutional investors with a combined $\$ 87$ trillion assets is part of the carbon disclosure project which is analyzed in this dissertation.

The recent developments on climate change are a reflection of the importance governments and firms have placed on their socially and environmentally responsible activities. They emphasize the radical change in the way people look upon how MNEs are related to their natural environment where they function, their relationship with 
investors, local communities, workers, domestic companies, suppliers, and host governments (Ioannou and Serafeim, 2012). This is evidently a great leap forward from the traditional view mainly suggesting environmental policies and practices of a firm having a significant influence on the cross-country legitimacy of the firm (Bansal, 2005) and also their reputation across cross-country institutional environments (Dowell et al, 2000). The ninth principle of the United Nations Global Compact exhorts businesses to "encourage the development and diffusion of environmentally friendly technologies". The supporting role played in social responsibility by transnational corporations has already extended beyond their own legal boundaries and often increased their influence over the activities of value chain partners. (Transnational Corporations, UNCTAD August 2011).

The importance of business in global environmental governance has been specifically pointed out by scholars (Levy, 2005). The governance by MNEs is far more difficult in the case of global climate change, where greenhouse gas emissions are diffused across and woven with business processes of production and transportation system of the modern economy (Ruggie, 2004).The period after the recent financial crisis, in particular, has provided an opportunity to overhaul the financial system across the world and also during that process to address climate change concerns (Shrivastava and Busch, 2013) as investors are increasingly considering climate change as a risk factor in business (Mercer, 2011). So businesses have started considering climate change strategy (climate strategy) as fundamental for their competitive strategy even though governmental regulatory pressures may have forced many of the firms to comply with the rules in the initial stages (Enkvist et al., 2008). The notion that businesses can provide 
solutions to combat climate change has received enough attention for businesses to acknowledge this on their agenda (Pinkse and Kolk, 2009). What is more interesting is that multinational companies (MNEs) act as a guiding factor pushing innovation and promoting learning that is ultimately resulting in increased firm value (KPMG survey, 2011). Investors now expect to get information about environmental “externalities” such as carbon dioxide emissions which investors believe is key to firm performance (Lubin and Esty, 2010) and, thus, 'investor-driven governance networks’ are playing an important role in global economy (MacLeod and Park, 2011). The decision making process of managers is crucial in the technological innovation process for a firm as the legitimacy of the innovation process and/or product is very much linked to and coevolves with ‘sociopolitical legitimacy’ (Hall et al., 2014). Confirming this point, a Goldman Sachs Report (2009) found that, among Global 800 companies with average market capitalization of US\$ 3 billion across the areas of performance key to their industries, 60 percent of those companies have assigned either their board members or their top management with clear duties and responsibilities to ensure carbon emission reduction of the company.

Lundan (2011) in a book review aptly puts that the fundamental difference in the strategies related to a global concern of climate change with that of traditional issues such as toxic pollution, more local in nature, is an important issue that international business research has to address. There is a need to empirically test assumptions of new frontiers in international strategy (Ricart et al., 2004). However, there are very few empirical studies at firm-level on climate change, an issue which Pinkse and Kolk (2009) call a 'distinctive international business issue' where institutional failures across countries 
matter. In this context, voluntary sustainability initiative gains prominence as a governance mechanism for promoting the development of voluntary environmental standards (Wijen, 2014). Even though broader areas of corporate governance and environmental performance have been empirically studied earlier, the results are both fragmented and contradictory (Walls et al., 2012).

This dissertation takes into account the relevance of Hoffman’s (2005) and Pinkse and Kolk’s (2009) call for considering controls on Green House Gas (GHG) emissions as a strategic concern induced by market forces rather than just an environmental issue arising out of social and regulatory pressures. Since MNEs can make significant contributions for a low-carbon economy through their global value chain process modification, technological upgradation, and related innovation in accordance with the national, international and supra national rules (World Investment Report, 2010; Ricart et al., 2004), the need to integrate these considerations into core business operations and strategy (Porter and Kramer, 2006) can be expected to vary with the orientation of MNEs. MNEs also differ in their environmental capabilities and environmental performance requirements based on a variety of factors. Factors such as available resources and capabilities, scale and scope efficiency of operations, reputational requirements, industry requirements, host country requirements, and home country environmental standards, are likely to affect environmental strategy for MNEs. In the context of a distinctive global environmental concern of climate change, therefore, this dissertation argues the superior effect of global-oriented MNEs as compared to regional-oriented MNEs on the environmental performance, in the context of adopting carbon emission reduction activities and incorporating them into the strategy of the firms. Since the strategy of 
multinationals is emphatically influenced by their home country (Elango and Sethi, 2007; Porter, 1990), this dissertation would also consider two different groups of multinationals, examining the effect of country of origin on environmental performance.

This dissertation investigates the effect of firm-level, institutional level and industry level associations on strategies relating to climate change. We argue that there would be difference among firms' regional- or global-orientation in adoption of climaterelated strategies that will be reflected in their environmental performance (Rugman and Verbeke, 1998; 2004). The two research questions put forth are: a) whether MNEs with global-orientation have better environmental performance compared to firms with regional-orientation on issues of global scope such as adopting climate change strategy; b) whether the home country of the MNE affects the environmental performance of MNEs originating from Europe and U.S. This dissertation uses resource-based view (RBV) and institutional theory as the theoretical lens to study the issue while drawing from the regionalization concept of Rugman and Verbeke (2004). This study is expected to enhance the understanding of 'sustainability' at the firm level in the context of a global phenomenon, climate change, a major concern of all stakeholders and especially institutional investors. In this dissertation, the expressions climate change performance, climate strategy, and carbon performance are used interchangeably to denote environmental performance.

The dissertation is arranged as follows. The second chapter will deal with the literature review, followed by theoretical framework and hypotheses development in chapter three. Chapter four consists of methodology; chapter five narrates the results followed by a discussion in chapter six. 


\section{CHAPTER II}

\section{LITERATURE REVIEW}

\section{SUSTAINABILITY}

Since Taylor's (1911) influential work on the systemized, scientific, and efficient approach to management, organizations have evolved through a highly transactional to transformational management (Delios, 2010). During this evolving phase, socially favorable change and socially oriented initiatives would increase the firm's expenses (Ambec \& Lanoie, 2008). Nevertheless, the flow of private-sector investment into the clean technology market place has been estimated at more than $\$ 200$ billion a year - with accelerated growth not just in the developed countries such as U.S. and Europe but also in China, India, and the developing world (Lubin \& Esty, 2010). These companies are investing substantially in these initiatives: a) to comply with the national and international regulation on climate change, especially after various national governments started ratifying the Kyoto protocol, and b) many companies have found that sustainability and green firm specific advantages are a best fit for their strategic growth.

Laszlo et al. (2005) described how stakeholders are becoming a new fast-growing source of business advantage. They offered a practical approach to building competitive advantage by identifying and acting on stakeholder-related business risks and opportunities. The most commonly used distinction of environmental technologies is between end-of-pipe (EOP) and cleaner technologies (Del Rio 2009). The author considered cleaner technology as a superior choice because it cuts waste at the source. 
Further, the author also emphasized the importance of taking into account for future research both internal and external factors to the firm and their interplay with environmental technologies into account. Wagner (2007) identified how environmental management system (EMS) and the interaction with environmentally concerned stakeholders are associated with the probability of firms pursuing innovation in general, and specifically, environmental innovation. The author found that the level of EMS implementation is what matters, not the signal from certification that takes place (or does not take place) after implementation.

The potential benefits of adoption of 'green' technologies and building of a 'green’ image by firms are explored by Chen (2008). Previous research had pointed out that companies are compelled to engage in environmental management to comply with regulations and also to appeal to ‘green’ consumers (Berry and Rondinelli, 1998; Hart, 1995; 1997; Rugman and Verbeke, 1998). Chen argued numerous benefits accrue from environmentally friendly innovation: first mover advantages in different markets, 'green’ product differentiation from competition, higher prices for green products, pre-empting consumer backlash to irresponsible practices while promoting a positive corporate image and a further subsequent competitive advantage from these activities (Chen et al., 2006). Videras and Alberini (2000), in their study of manufacturing firms in the Standard \& Poor 500, point out that gaining competitive advantage as one of the possible reasons for firms to participate EPA’s voluntary environmental program.

The study by Christmann (2004) found that multinationals tend to standardize different environmental policy dimensions as a result of characteristics of multinationals also yielding to pressures from different external stakeholders. Their study further 
implied that multinationals are less likely to exploit the differences between countries in environmental regulations to operate in countries with weak regulations for dirty operations. At the same time, another study in the USA where environmental regulations are strong, foreign owned establishments generated more waste, but also managed more waste than U.S. owned establishments (King and Shaver 2001). So there seems to be no commonality in the operations of multinational companies as far as their operations and location of operation is concerned. According to Porter and Kramer (2006), four broad reasons for corporate social responsibility were: "moral obligation, sustainability, license to operate and reputation.” Hart (1995) articulated a natural-based view of the firm and discussed the competitive advantage a firm can attain through three inter-related, path dependent activities: "pollution prevention, product stewardship and sustainable development.” These innovative environmental strategies by firms help in development of firm-specific capabilities which in turn give competitive advantage against competitors. This view propounded by Hart is an important contribution in order to build theory on environmental protection by the firm while building competitive advantage. This aligns with the transformational nature of multinationals' (Bartlett and Ghoshal, 1989; Delios 2010) conception of transformational relationship of MNEs with the stakeholders.

Hoffman (1999) showed that institutional influence can lead firms to conform to uniform or similar environmental strategies, whereas recent research (Delmas and Toffel, 2008; Walls and Hoffman, 2013) is focusing on why firms are having heterogeneous environmental strategies for the same issues that they face. Ruggie (2004) had found that 
greenhouse gas emission is very much diffused and interwoven with modern production and transportation systems.

In the twenty-first century, issues regarding corporate governance have shifted progressively toward contemporary social issues such as climate change that are relevant to various stakeholders such as law makers, consumers, shareholders, and corporate managers (Walls et al. 2012). Some firms in the U.S. took advantage of the uncertainty that the Kyoto protocol brings about to make their own strategic objectives for reduction of Green House Gas (GHG) emission even though the U.S. lacked a mandatory GHG emission reduction program (Hoffman 2005). According to Hoffman (2005), climate change represents a radical transition similar to the transition that happened from typewriters to computers except thatclimate change is a recent and unique global phenomenon. This argument is recently augmented by Lubin \& Esty (2010), when they suggested that climate change related strategy is a 'megatrend' that is happening similar to the earlier 'megatrends' such as Information Technology Revolution and Quality Management Circles. Pinkse and Busch (2013) examined why firms still adopt a constraint of adopting carbon norms.

Christensen et al (1987) highlighted the environment to be dynamic, resulting in changes in corporate strategies. Investment in sustainability improves the competitiveness of a country (Esty and Charnovitz, 2012) as well. Lundan (2011) opined that MNEs are likely to lead, shaping many of the solutions to mitigate climate change, which, according to Porter and Kramer (2011), "need strategic corporate social responsibility to make the most significant social impact and reap the greatest profits.” One of the important components of strategy as stated by Christensen et al. (1987) is to acknowledge 
obligations to societal actors other than internal stockholders or primary external stakeholders. Firms in high carbon emitting industries are in the process of reducing carbon emission of their business process, activities and operations (Gow, 2009).

The notion of Lubin and Esty (2010) that sustainability is an emerging business 'megatrend' bringing about fundamental and persistent changes in the way companies compete (Lubin and Esty, 2010) seems to widely acknowledged in the current research agenda (Berchicci et al., 2012; Hoffman, 2005; Pinkse and Busch, 2013) by providing priority to research on sustainability from the perspectives of internal competencies of firms as well as from the external opportunities for the firm. Their emphasis is on the fundamental shift which persists, compelling firms to adopt a climate change strategy. Ruggie (2004) also had suggested that, unlike the existing environmental issues which have global concern such as those pertaining to marine pollution in high seas, climate change would be more challenging because of the need to fundamentally shift the production and transportation processes of the world's modern economy. Aligning of sustainability and climate change integration is found as a priority strategy, for example, BMW group (CDP Global 500 Report 2011). According to Porter (1996), strategy refers to making trade-offs to choose a distinct set of activities in order to achieve a sustainable competitive advantage that extends beyond simply attaining operational effectiveness. Strategy requires constant change (i.e., rediscovering strategy) since it is important for firms to achieve uniqueness and to avoid competitive convergence. Thus, according to Porter, leadership of a firm ensures that a given firm is able to shift its productivity frontiers outward by creating strategic fit to attain strategic positioning. Increasing demand for climate change strategy is related to the firm's recognizing the demand for 
low-carbon technologies (Hoffman, 2005). Rowlands (2001) suggested that the ability to adapt to climate change depends on multiple strategic options a firm may pursue. The best approach may be to encourage new technologies keeping in view long-term sustainable development through Clean Development Mechanism (CDM). Bansal and Gao (2008) stated the need for developing specific firm capabilities, capital investments, and adherence to regulations to deal with technical challenges thrown by the environmental issues. At the national, regional, or international level, the support of firms is critical as it represents the productive resources of the economy and is essential to achieve sustainable development (Bansal, 2002).

Kolk and Pinkse (2008) discussed how climate change can induce development of new firm-specific advantages (FSAs), or modify their current FSAs. Country-specific advantages (CSAs) act as the initiator of new firm-specific advantage development. Since nations differ in their environmental regulation and implementation, development of uniform FSAs is both difficult and not warranted. Even after the majority of countries ratified the Kyoto protocol, institutional failure in reducing climate change activities continues to vary by country (Kolk and Pinkse, 2012). The MNEs may try to develop environmental or 'green' FSAs that can be scaled across the borders through knowledge assimilation and transfered across their internal networks.

Previous studies on environmental strategy by the firms are mainly related to toxic pollution (Berchicci et al., 2012). The negative externalities focused on by earlier studies on environment and business tended to have local focus (Lundan, 2011). Alternatively, as Christmann (2004) pointed out, standardizing their environmental strategy is advantageous to MNEs to use their resources and also to manage those 
resources efficiently. At the same time, differentiation using Corporate Social Performance is used as a strategy by firms with lower levels of innovation (Hull and Rothenberg, 2008). The focus on research was on the local area of business and the environmental impact mainly based on toxic pollution or other local environmental issues based on saliency at a particular location. Lundan (2011), recently observed that one of the important international business research issues is the degree to which strategies related to climate change are fundamentally different from issues related to toxic pollution which until now have been studied more in International Business research.

Cordano et al. (2010), based on their study of US wine industry, observed that appropriate Environmental Management Practices, when voluntarily adopted by firms and supported by trade associations, can facilitate change in fragmented industries, e.g., the wine industry. Hoffman (2005) made similar observations on US companies adopting Green House Gas reduction activities even though regulations did not demand it then. The strategic reasons for companies adopting and following voluntary greenhouse gas emission reduction activities depend on the priorities and policies of each company and therefore are found to vary depending on the company (Hoffman, 2005). These companies were found to be multinationals, or primarily U.S. market oriented, from $\$ 350$ million to $\$ 186$ billion annual sales. Hoffman also observed that these companies included public, private, and government-owned and were from very diverse industry sectors such as oil, pharmaceuticals, and financial services. It would be interesting to note that the main conclusion of the paper by Sharma and Vredenburg (1998) is that proactive environmental strategies to counter uncertainties helped firms gain distinct environmental capabilities in the Canadian oil and gas industry. They found that environmental 
responsiveness strategies explained about 20 percent of the emergence of environmental capabilities. These capabilities include technological innovations, efforts to reduce waste and energy use, attempts to build partnerships, and so on.

The studies on environmental performance have used different measures for measuring it. For example, Al-Tuwaijri et al. (2004) proposed environmental performance as the ratio of the amount of hazardous waste recycled to the amount of hazardous waste generated and computed as a disclosure measure. According to King and Shaver (2001), conflicting predictions for the environmental performance of foreign vs. domestic firms exist in the literature. They elaborated that some authors found foreign firms to have difficulty in adapting to the local host conditions. Another group suggested that, depending on the home country regulations of the foreign firm, they will have superior technological capabilities and have better environmental performance at host countries.

The relationship between environmental performance and financial performance is also varied. Hull and Rothenberg (2008) state support for the argument made by Waddock and Graves (1997) i.e., Corporate Social Performance (CSP) pays off. Their interaction result showed that firms with a low level of innovation may use CSP as a strategy to increase profitability. Another incentive for managers is found in polluting industries where focusing on improving their firm's environmental performance is often financially rewarded (Berrone and Gomez-Meija 2009).

Sustainable development is steadily becoming prominent in international investment policymaking (WIR, 2012) and it implies investment policy should have increasing emphasis on the promotion of specific types of investment such as "green 
investments” and "low-carbon investment” (WIR, 2010). "Low-carbon foreign investment can be defined as the transfer of technologies, practices or products by TNCs to host countries - through equity (FDI) and non-equity forms of participation - such that their own and related operations, as well as use of their products and services, generate significantly lower GHG emissions than would otherwise prevail in the industry under business-as-usual (BAU) circumstances” (WIR 2010: 103).

\section{REGIONALIZATION}

Rugman and Verbeke (2004) studied how the sales of 380 companies varied across NAFTA, the European Union, and Asia, which they called as 'triad' regions. They found that more than eighty percent of the sales of more than 80 percent of these firms was within their home region 'triad'. So the authors argued that home region concentration of sales would have definitive impact in formulation of optimal strategies of the companies. They, therefore, suggested that different activities in the value chain could be related with varying levels of globalization and linking of upstream firmspecific advantages (FSAs) with downstream FSAs such as branding, which often follows a home region-oriented strategy.

Earlier, from a resource-based view, Rugman and Verbeke (1998b) argued that strong response from the firms to an environmental obligation warrants developing and enhancing strategic capabilities which should be sufficient enough for the firms to outperform the average competitor by being green alone. They used the micro-level view point of the company or its managers to investigate, because green investments are initiated by the company, its drivers, and its facilitators. They also discussed macro- 
aspects of the role of environmental regulations on the competitive position of countries and the resulting micro-level aspects, of consequences for the multinationals. Rugman and Verbeke (2008) extended their research by focusing on the difference between manufacturing and service industries apart from adding asset dispersion as another parameter. Climate change being a global issue, MNEs may not be able to approach this as a separate issue for each country (Pinkse and Kolk, 2012) and this could mean that there is a need for regional or global-orientation in MNEs dealing with this issue. Consequently, the firms that are regional and global could have different motivations and capabilities in dealing with an environmental issue of global dimension that at the same time warrants different institutional obligations in different countries.

Tong et al. (2008) observed that country-industry interaction has value in the growth options of firms based in different countries. Earlier research suggested that good environmental performers had a positive association with profitability (King and Lenox, 2002). Climate change provides a situation for transition of products (Hoffman, 2005). Financially successful emission reduction warrants an evaluation of the MNE's strategic positioning with respect to its emissions. This can be a measure to instill sustainability in every link of their value chain. Further, Rugman and Verbeke (2004) pointed out that one of the major reasons that MNEs prefer regionalization to globalization was because they can integrate their value chain quickly and effectively. Alternatively, Christmann (2004), suggested that MNEs implemented uniform environmental policies to reduce complexity, similar to implementation of other functional policies on a global scale.

Multinationals that are competing internationally are exposed to different risks such as sudden fluctuation in prices of raw materials, dearth of raw materials at the 
sourcing point, unexpected and drastic changes due to innovative technologies sprouting up and disrupting the entire value chain of the company; and investing heavily in highly risky R\&D and capacity building which new entrants might heavily undermine (Jones and Levy, 2007). These risks are competitive in nature and those multinationals that have operations and sales in multiple countries, therefore, face higher risk.

The higher risk that MNEs face with increase in their multinationality, along with the supporting role played in social responsibility in extending beyond their own legal boundaries and increasing their influence over the activities of value chain partners (Transnational Corporations, UNCTAD August 2011), would mean MNEs with globalorientation would have much more risks than home region-oriented multinationals. Knudsen (2011b) suggested the UN Global Compact may be perceived less valuable for companies that primarily operate at home. The author also pointed out that those Western companies primarily producing or selling in the well-regulated home markets or host markets are less likely to benefit from UN Global Compact membership. Firms from countries whose economy was intertwined strongly with global economy were found to comply with UN Global Compact standards (Knudsen, 2011a). These differences seem to warrant different actions from globally and regionally oriented firms. Husted and Allen (2006) distinguished between 'local CSR' that reflects a firm's responsibilities to its local population vs. 'global CSR' that reflects a firm's responsibilities based on commonly accepted standards across countries and different societies. Apart from this, corporate social responsibility seems to be linked to an MNE's adoption of global and local environmental standards. There can even be financial implications for having stringent global environmental standards. In a study Dowell et al. (2000) found that firms with 
single global environmental standards have better market performance than those firms that are complying with lower environmental standards of host countries.

Christmann and Taylor (2001) in their study on China found ownership of assets across countries, having customers across countries, and exporting to developed countries resulted in the MNEs from developing countries voluntarily regulating their environmental performance. The geographic location to develop firm-specific advantages (FSAs) uses country-specific advantages (CSAs) as the starting point for developing or enhancing FSAs at the specific geographic locations within the corporation and, therefore, for the MNE's climate change policy, may pose a threat in one location and an opportunity in another location (Kolk and Pinkse, 2008). This is important strategy research which looks at developing firms-specific-advantages based on climate change. Similar views can be noticed in the publications such as the World Investment Report. For example, the World Investment Report (2010:100) exhorts businesses to actively contribute towards mitigating climate change. One of the major requirements suggested to achieve this end is to incorporate guiding principles on MNEs and foreign investment into climate regime policies. In other words, it is about integrating international investment policies into the climate change framework. Overall, global environmental performance and environmental capabilities development is not only a matter of firmlevel strategic consideration, but also have an increasingly crucial role in policy making and governance, both at the country level and at the supra national level.

Rugman and Verbeke (2001) highlight three levels of non-location bound advantages and location bound advantages, e.g., home country, host country, and networks. In another perspective, Manev and Stevenson (2001) suggested that large 
cultural distance may not always present insurmountable problems at the micro-level as previous research has indicated that managers can use strong expressive ties with peers with smaller cultural distance and can use strong instrumental ties with peers who are from larger cultural distance. They argued that horizontal links between the managers of various subsidiaries are important factors for organizational learning in the MNE. A firm from a country with well-developed institutional support is likely to be well-off (in good competitive position) as the country-specific advantages can facilitate the growth of the firm (Rugman and Verbeke, 2001). This would mean that MNEs from developing countries would have a disadvantage compared with the MNEs from developed countries (Cuervo-Cazzura \& Genc, 2008). The authors argued that on internationalization to other developing countries, developing country MNEs may, however, have an advantage over developed country MNEs because of former's familiarity in operating in a similar institutional context. The authors build on the theory that homogeneity of conditions between home and host markets is likely to be beneficial because they tend to face less liability of foreignness (Zaheer \& Mosakowski, 1997). The springboard perspective (Luo \& Tung, 2007) suggested the acquiring of strategic resources by developing country MNEs in order to reduce their institutional and market constraints in their home country. Successfully combining knowledge from across the border locations gives a competitive advantage because this knowledge tends to be acquired or replicated by other firms (Kogut and Zander, 2003; Martin and Solomon, 2003). By combining and exploiting knowledge from different subsidiaries in different locations, multinationals can improve their innovation quality and superior performance (Phene and Almeida, 2008). Husted and Allen (2006) found that global corporate issues 
had more or less the same priority for all MNEs, but global MNEs had less priority for corporate social responsibility that were country-specific as compared to the multidomestic and transnational MNEs.

\section{INDUSTRY TYPE}

Apart from countries, industries also establish regulatory processes for making sure that standards and quality are maintained (Campbell, 2007). State support is essential for the industry to effectively implement these regulations without which many times industry self-regulation fails (Karkkainen, Fung \& Sabel, 2000: 697).

The type of industry is expected to influence the environmental performance of firms (Hoffman 2005; Perez-Batres et al 2012; Lopez et al 2009). Berrone and GomezMeija (2009) found that CEOs in polluting industries focusing on improvement of the firm’s environmental performance are financially rewarded. Porter and Kramer (2006) pointed out that the potential impact of corporate social responsibility issues varied from business to business units, industry to industry and place to place. They also opined that implication of carbon emissions is likely to differ for different industries. For example, they stated that while carbon emissions could be a generic issue for a financial firm, it could have major negative impact on the value chain for a transportation-based company, while for a company that manufacture vehicles based on consumption of fossil fuels this could warrant an overhaul in their competitive strategy towards manufacture of non-fossil based vehicles. Any technological strategy for innovation has to consider overcoming technological uncertainty as well as societal uncertainty, and the latter involves multiple secondary stakeholders (Hall et al., 2014). The impact for societal acceptance is likely to 
differ with challenges a society is facing and the nature of the industry. Hall et al. (2014), further emphasized that science-based firms have a natural inclination to deal with the cognitive part of the legitimization process and to downplay the sociopolitical legitimization process.

To have financially successful emission reduction, firms require strategic positioning with respect to emissions and this is particularly important for companies whose product development process involves higher toxic emissions (Hoffman, 2005). Perez-Batres et al. (2012) observed that firms in 'dirtier’ industries were more transparent in sustainability reporting compared to firms in 'cleaner' industries. Lopez et al. (2009) mentioned previous studies (for example, Chadee \& Mattsson, 1998) to show that internationalization patterns varied with industry type because of industry-wide differences in complexity and cost in internationalization. Measures to control greenhouse gas emissions are more challenging for high carbon-dependent sectors that include coal, gas, autos, electricity generation, transportation, cement, agriculture, aluminum, and paper (Jones and Levy, 2007; Pinkse and Busch, 2013). However, according to Lash and Wellington (2007), regardless of the industry type such as the traditional smokestack industry or a ‘clean’ business like investment banking, companies are increasingly dealing with the effects of climate change.

While conceiving the Carbon Disclosure Project, the Rockefeller Foundation estimated that stock prices of firms could fall up to 40 percent for industries that are carbon-sensitive and 29 percent for non-carbon sensitive industry, e.g., banks that do not have any carbon mitigation strategies. The Rockefeller Foundation thus perceived differential risk for high carbon-emitting and low-carbon emitting industries as far as 
stock market reaction for the implementation of carbon risk management strategies was concerned. According to Verrecchia (1983), the firms' decision to disclose or not disclose their corporate information is contingent upon the costs associated with the disclosure. Unless the perceived benefits associated with the disclosure are greater than the proprietary benefits, firms will not disclose. Kolk and Pinkse (2008) observed that carbon dependency is high for firms in certain types of industries that are heavily dependent on fossil fuels, such as cars and coal based electricity generation. Reducing their carbon emissions in the short term is difficult because it would demand radical change in the configuration of their principal assets and machineries.

Lyon and Shimshack (2012) in their study based on Newsweek’s Green Rankings, ratings on company environmental disclosure, used an event study methodology and found that the rankings had significant impact on shareholder value. Firms in retail, financial services, pharmaceuticals, banks and insurance, technology, and consumer products received favorable sustainability ratings from Newsweek’s Green Rankings while those in the utilities, healthcare, basic materials, and oil and gas sectors received, on average, unfavorable performance ratings (Lyon and Shimshack, 2012). According to a report by Pike Research in Boulder (Greenbiz.com, April 2012), energy efficiency is an area where American industries can increase their competiveness. The report examined four categories: energy intensive industries; large non-energy-intensive industries; midsized non-energy intensive industries; and small manufacturers. With tightening of regulations, firms in heavier polluting industries or those with older technologies often wage a constant battle to reduce emissions incrementally (Bansal, 2002). According to Ghemawat (2001) the industry also has an impact on the international commerce of the 
firms. Cho and Patten (2007) classified firms into environmentally sensitive and nonenvironmentally sensitive based on industry membership. Further, they classified worst performers and better performers based on the Kinder, Lyndenberg \& Domini (KLD) database to test their hypotheses. They found that among non-environmentally sensitive (non-ESI) firms there was significant difference in performance in their non-monetary disclosure. The worse environmental performers had a better non-monetary disclosure compared to better environmental performers. Pinkse and Busch (2013) found that firms in certain industries, e.g., electric firms, where cost-effective coal based power plants are higher polluters than those with fossil fuels, would find it very difficult to reduce carbon dependency in the short run. Amit and Schoemaker (1993) introduced the concept of strategic industry factors that are dynamic and varying where each firm with managers who behave with ambiguity and often arrive at suboptimal choices try to align their strategic assets in tandem with strategic industry factors to get the competitive advantage. So there will be an attempt to align firm resources and capabilities to the changing strategic industrial factors and manager's decision making process. Organizational structure and processes contribute to the effectiveness of how a firm becomes successful. This is pertinent in a disclosure of environmental performance, as disclosed information is relevant to investors and other stakeholders who act on that information (Lewis et al., 2014).

\section{INSTITUTIONS}

\section{European vs. U.S. Multinationals:}

Institutions represent the rules of the game that influence and structures human behavior and thus organizations are bounded by those rules (North, 1990). The 
institution-based view has its focus on the institutional conditions within countries which may be formal or informal; static or evolving (North, 1990; Peng et al., 2008). This is the economic view of institutions. Businesses are not usually stand-alone entities, but are embedded in the institutional context of a nation and hence managers have to take decisions within the context of the institutional environment of firm operations. This would mean that the performance of firms has an association with the institutional context of firm operation (Busenitz, Gomez, \& Spencer, 2000). Ingram and Silverman (2002: 20) argued that institutions directly determine the options a firm has as it formulates and implements strategy to create competitive advantage.

In a seminal article, Scott (1995), proposed three dimensions to measure institutional distance. The measures are the regulatory, cognitive, and normative aspects of institutions. Based on the sociological view proposed by Scott, institutions comprised of regulatory, normative, and culturally-cognitive pillars that, together with associated activities and resources, provide stability and meaning to social life (Scott, 1995; 2008). Regulatory pillars are the laws or regulations, and they often use coercive mechanisms of control. Legal institutions have dual roles of constraining the actors as well as empowering action. Normative rules "introduce a prescriptive, evaluative and obligatory dimension into social life” (Scott, 2008). The basis of compliance is a social obligation and is referred to as normative isomorphism (Dimaggio \& Powell, 1983). Finally, the way individuals interpret these institutions is cognitive and is influenced by cultural factors. Institutions supported by one pillar, with time and as a result of environmental changes, can be sustained by the other two pillars. Scott argued that the institutional 
distance implied a difference in these three aspects between nations, and therefore, can be expected to influence the strategic similarity that firms pursue in different countries.

MNEs have better access to different national and supranational stakeholders including the United Nations, who are in a good position to contribute to the creation of global behavioral norms (Kolk \& Van Tulder, 2005), because they might have convergence in the perception of climate change measures as the cognitive, normative, and regulatory institutional pressures change (Scott and Meyer, 1994), and are likely to have some similarity in environmental policies. There is a potential liability of origin (Ramachandra \& Pant, 2010) where, in a global arena, an MNE’s green reputation tends to be closely associated with the political stance of their home country (Dunning \& Lundan, 2008).

Legitimacy has a role in the process because institutions seek to establish and maintain their legitimacy. A firm gains legitimacy by acting in accordance with the rule or laws, or by adhering to normative standards and on moral grounds, or on the basis of being recognizable and culturally supported. MNEs based in different home and host countries need to gain legitimacy because these MNEs have their own institutional profiles (Kostova and Zaheer, 1999). They argued that, therefore, an understanding of institutional change, and the ways that firms can influence such change, is essential to comprehend strategy.

One way to achieve legitimacy for MNEs in the host environment where they operate is by adapting business practices and processes to the host country's institutional context (Kostova and Roth, 2002). However, operating in different institutional contexts in a globalized world warrants the MNEs to bring in what the authors christen as 
'international institutional legitimacy' and standardize their managerial actions across the different institutional contexts, while increasing the transparency of their operations. However, according to Kostova, Roth \& Dacin (2008) institutional embeddedness in host countries is more complex than that in a home-country setting as MNEs operate in many different host-country contexts that are often divergent or even inconsistent. This was also found in the context of climate change mitigation strategy (Pinkse \& Kolk, 2009). It is interesting to notice that there was a tussle between the U.S. government (also China, Russia, and India) and European Union over the European Union plan to charge foreign airlines for their carbon emissions (Financial Times, April 17 2012). Cantwell et al. (2010) succinctly puts this process as "the interplay between dynamic configuration of MNE activities and the evolution of external and internal institutions is predominantly determined by how the MNEs adjust their strategies and structures to cope with the uncertainty and complexity of this interplay.”

Firm-specific advantages (FSAs) arising from institutional embeddedness have conventionally been considered as a home-country advantage (Murtha \& Lenway, 1994). Based on their home-country, firms are likely to differ in their FSAs because countries differ in their abilities and priorities to assimilate or reject pollution (Christmann and Taylor, 2001). However, another point of view was put forth by Christmann (2004). The author argued that MNEs have an influential role in transferring green best practices across geographical borders, helping to fill institutional voids by leveraging expertise built up in other contexts (Rugman and Verbeke, 1998). The transfer and assimilation of environmental best management practices promotes the possibility of environmental standardization across the countries where the MNE is operating. 
According to King and Shaver (2001) existing literature revealed conflicting results for the environmental performance of foreign vs. domestic firms. They suggested that the capabilities of the firm are dependent on the conditions and regulations in the foreign firm's home country. There are many studies that support this finding. For example, institutional pressures significantly determined the strategic responses of a firm in the oil and automobile industries (van deWateringen, 2005). Campbell (2007) in a study of determinants of Corporate Social Responsibility showed that the way firms treat their stakeholders depended on the institutions that exist to protect them. Delmas (2002) found, interestingly, that only very few firms from US implemented ISO 14000 as compared to their European counterparts. Purvis and Grainger (2004) suggested that, based on the perspective of developed countries, sustainable development is primarily about conserving the environment; from the perspective of the developing world, it means continued pursuit of development with the aim of reducing poverty and attaining the status of modern societies.

Kolk and Mulder (2011) suggested that the inherent regulatory uncertainty in climate change policy may benefit some companies if they recognize and capitalize on the opportunities early to shape emerging rules and framework in their favor. The authors considered institutional differences between Europe and US where the former encourages adopting certification system for environmental management standards, whereas the latter institutional environment did not support certification process. After the 1987 Montreal Protocol US companies were actively challenging climate science in reducing the ozone depleting substances as industrial countries were mainly targeted for carbon emission reduction activities (Jones and Levy, 2007). 
The legal, financial, property rights, and other institutions are found to differ across nations and, in turn, stakeholders' influence on upper echelons varies accordingly (Aguilera \& Jackson, 2003; Roe, 2003). Sethi and Elango (1999) suggested that factors affecting firms in the global arena include resources of the firms, the structure of the industry in which the firm operates, and home country factors. According to the authors, 'country of origin effect' is comprised of (1) resources and industrial capabilities, (2) cultural values and institutional norms, and (3) national government's economic and industrial policies.

According to Bansal (2002), in order to address the challenge of sustainable development, it has to be institutionalized in the regulations, norms, and mindsets of Americans, as well as in the systems, structures, and practices of organizations. Campbell (2007) cited that the previous literature highlighted a comparison between Sweden and the U.S. to point out differences. Sweden, through consultative process with various stakeholders such as environmentalists, business people, political parties, and bureaucracy, came up with pragmatic regulatory mechanisms addressing both economic and environmental consequences. However, in the U.S., owing to lesser consultative processes, non-pragmatic regulations were passed resulting in less effective regulation than in Sweden (Lundqvist, 1980). According to Chandler (1962), the industry selfregulatory agreements of firms were often quelled by courts when legal issues arose between the member firms and they moved to court cases. This is predominantly observed in the U.S. Maignan and Ralston (2002) studied firms in three European countries i.e., France, Netherlands, United Kingdom, and U.S. to understand their commitments to socially responsible behavior. They found that firms had three 
motivations for socially responsible behavior: (1) managers valued socially responsible behavior; (2) managers believe that this improves firm's financial performance, and (3) stakeholders such as NGOs, law makers and customers force firm to behave in this manner. They found differences in responses across the four countries. Acemoglu et al. (2001) relied on history to explain why different institutions are better in some countries compared to others. They tested that colonies where Europeans faced higher mortality rates are today substantially poorer than colonies that were healthy for Europeans. The rationale behind this is that Europeans built institutions in colonies where they could survive. In places where the mortality rate was high, they could not build those institutions and they just got resources (gold, ivory, etc.) and left the colonies. The mortality source for this study was the malaria and yellow fever.

From an economic perspective, institutions can impact the economy. Institutions affect the performance of the economy by their effect on the costs of exchange and production (North, 1990). The political environment has been found to impact MNEs and entry mode sequence (Delios \& Henisz, 2003). Henisz (2000) found that political hazard affects country growth rates. Also, according to Henisz and Zelner (2001) honest commitment from the government not to acquire or expropriate the assets of MNEs will result in reduction in the risk of investment in the host country. In addition, under strong institutions there is no need to divert financial and managerial resources from economic activity to political rent seeking, enabling higher investments in tangible economic infrastructure. Responding to weak institutions by forming business groups (Khanna \& Rivkin, 2001) or by applying relationship based strategies (Peng, 2003) diverts company resources. Khanna and Rivkin (2001), based on their study of business groups in fourteen 
emerging markets, found that sustained difference in profitability may vary across institutional contexts.

Guler et al. (2012) found the diffusion of ISO quality standards occurred through country level institutions beyond the firm's technical aspects and efficiency. Peng (2003), following the institutional changes in transition countries, predicts that as institutions develop, firms “move from a relationship-based, personalized transaction structure calling for a network-centered strategy to a rule-based, impersonal exchange regime suggesting a market-centered strategy”. The driving factors or principal norms of European external climate policy are: (i) effective multilateralism and adherence to international law, (ii) sustainable development, and (iii) the precautionary principle and climate science (Van Schaik and Schunz, 2012). By using the precautionary principle the European Union takes the initiative in public policies which are yet ambiguous and debated substantially in the scientific community. This seems to be a big impetus for the European Union to uphold climate change science. Chandler (1990) had suggested the influences that the home country of the MNE have on the subsidiaries during internationalization. Phene and Almeida (2008) suggested the positive effect of home country firms on the scale of subsidiary innovation. The effect of normative power in home country diffusion of environmental policies in the context of climate change was studied by Braun (2012).

Van Schaik and Schunz (2012) observed that the leadership of the European Union in climate change related negotiations is because of the emphasis of norms in their institutional context. They further elaborated, based on discussions in the Kyoto Protocol in 1997, that the European Union, while standing up for legally binding carbon emission 
reduction targets for industrialized countries, agreed for developing countries not to reduce their emissions. However, the stand of U.S. differed. The U.S. wanted developing countries such as China and India also as part of the accord. The argument of U.S. was the developing countries in the near future will increase their carbon emissions in an exponential manner. So the U.S. focused on the economic interests. U.S. and United Kingdom lagged behind Germany in strict air-pollution regulations which enabled German companies to thrive in environmental technology production and related trade (Porter, 1996).

\section{INSTITUTIONAL DISTANCE}

The institutional contexts where MNEs operates across borders differ. According to Ghemawat (2001) distance in terms of cultural, administrative, geographic, and economic distance matters for the international commerce of the firms. The impact also varies along with product and industry type which supports the conceptual model of this paper. Institutional distance is another important reflection of the cross-country difference. It can be captured and measured as cross-country differences (Kostova \& Zaheer 1999). A definition of institutional distance was given by Xu and Shenkar (2002: 608 ) as "to the extent of similarity or dissimilarity between the regulative, cognitive, and normative institutions of two countries”.

The International Business literature has consistently considered the host countrymarket conditions a motive for the MNE to internationalize (Galan, Gonzalez-Benito and Zuñiga-Vicente, 2007). The firms are strongly interwoven in the broad institutional and industrial context where they operate (Delios, 2010) and can be considered as dominant 
social institutions. So the credibility of the political institutional context and regulatory policy are important to the MNE in determining the level of investment in the host market (Delios and Henisz, 2003). One way to minimize the effect of political hazard is the ability to learn, to detect, and to safeguard against opportunistic behavior by host government or partners (Henisz, 2000). As the distance between the home and host country increases, with its regulatory/institutional, cultural, and economic components, the non-location bound FSAs begin to decay (Rugman and Verbeke, 2008).

The attention of researchers recently has been increasingly focused on environmental or green aspects of institutional commitments and differences. AguileraCaracuel et al. (2012) showed that the environmental institutional distance between the home country and the host country, along with the MNE's financial performance, had an impact on the environmental standardization decision in multinational companies.

Recently, Berry et al. (2010) showed that how different distance dimensions can be used to examine how, why, and when cross-national distances influence managerial decisions. Measuring the efforts for sustainable development by companies and providing those measurements to the relevant stakeholders can reduce institutional distance between societal actors and firms (Bansal, 2002). Aguilera-Caracuel (2012) highlighted the need for further attention on institutional distance in terms of environmental issues between countries where headquarter and subsidiaries of a firm are located.

Low institutional distance may help adjust the legitimacy requirements of a country that has a similar institutional profile to the home country of a MNE (Kostova and Zaheer, 1999; Xu and Shenkar, 2002). Transferring of strategic resources to the subsidiaries, then, is easier, favoring a standardization decision. Internal creation of 
environmental capabilities and standards within MNEs can also happen if the institutional distance is high (Christmann, 2004), thus standardizing their environmental practices in order to attain international legitimacy in all the locations where the MNE operates (Kostova et al., 2008). Standardizing decisions of managerial practices will be more likely when there are low legitimacy requirements owing to low institutional distance, and will be less likely when high institutional distance prevails because of liability of foreignness (Aguilera-Caracuel, 2012). Even though climate change is a global issue where most of the nations are involved, there is no binding global agreement to all the nation actors, as country level institutional failure is a key issue (Pinkse and Kolk, 2012). Interestingly, companies are also found resorting to voluntary environmental regulation and disclosure as a signal to regulatory authorities not to formulate stringent regulations and to avoid specific monitoring of the environmental activities of a firm (Lyon and Maxwell, 2002). This behavior is clearly visible in industries such as chemical manufacturing and nuclear power plants (Reid and Toffel, 2009).

The type and functioning of MNEs have relevance to their strategy. Martin and Jarillo (1991) suggested an integrated firm characterized by high coordination, while Roth and Morrison (1992) focused on decentralization of decision making, i.e., giving subsidiaries global responsibilities/mandates in specific areas. In the case of global mandate, the subsidiaries work with headquarters to develop and implement strategies. Further, all the subsidiaries of a MNE cannot be treated equally as the subsidiaries have different capabilities (Bartlett \& Ghoshal 1986; Roth \& Morrison 1992). This is important for this dissertation’s research question because it suggests varying opportunities and incentives in following strategy at the subsidiary level. Bartlett (1986) 
suggested three types of organizations, i.e., global, multinational, and transnational. Global organization is world market oriented, and its profit relies on economics of scale, global manufacturing, and centralized control of operations. The multinational organization is localization oriented and focuses on the differentiation of products in each country. The transnational organization tries to coordinate operations in all host countries and focuses on the economies of scale, economies of scope, and differentiation at the same time. Transnational organization is a preferred strategy /structure because, according to Bartlett (1986), in host countries both efficiency and responsiveness are required. This was later supported by Prahalad and Doz (1987). In their Integration Responsiveness framework the authors suggested that almost all companies competing internationally need to balance between two forces: being responsive to local economy while also being able to benefit from integration. They classified firms under three types: global, multifocal, and responsive. This classifications of strategies is significantly influenced by institutional distance. The expense and benefits that a firm may accrue because of voluntary disclosure are mostly uncertain and hence decision to disclosure may depend on the top management of the company (Clarkson et al., 2008). Phene and Almeida (2008) found the multinationals can improve their performance through quality innovation using their capabilities to combine and exploit the knowledge from different subsidiaries in different locations. They argued that experience and knowledge gathered from the firm affiliates in the host countries is crucial in influencing the scale and quality of innovation of the multinational. When there is a global environmental challenge in the form of climate change, it would be easier and more important for global-oriented MNEs 
to opt for standardization of business operations and capabilities across its operating affiliates.

\section{CARBON DISCLOSURE PROJECT}

Espeland and Sauder (2007) in their study on law school responses, by school administrators, faculty and staff to the school rating by U.S. News \& World Report rankings observed that poor ranking diminished the attractiveness of school to external funders and high quality applicants. Voluntary or non-voluntary projects that publish firms' environmental performance have been characterized as the "third wave" in environmental regulation, after command and- control and market-based approaches (Tietenberg, 1998). Earlier, Harte and Owen (1991) analyzed annual reports of British firms and found a general increase in firms' environmental disclosure over time, implying the willingness of firms to disclose their own environmental standards. Some firms also reveal the industry standards. Some firms reveal both, firm’s environmental standard and industry environmental standard, without providing details. Consistent with the observation of Harte and Owen (1991), the 'third wave' wave perceived by Tietenberg (1998) seems to have taken a key role in determining environmental performance of the firms because stakeholders are having increasing interest voluntary disclosures reports on sustainability.

Campbell (2004) used word count technique for analysis and found positive association between the extent of environmental disclosure and industry classification. The author suggested that social legitimacy was the reason for variation in environmental disclosure over the years and across industries. There were differences in the types of 
disclosures. Walden and Schwartz (1997) categorized environmental disclosures into financial or nonfinancial disclosures. The study revealed a significant increase in both the quantity and quality of environmental disclosure across all the four industries they studied.

The carbon disclosure report is published each year by a London based Carbon Disclosure Project (CDP). Eighty percent of respondents of a survey of managers of top 500 companies in the world foresaw their firm would be affected by the climate change and the related changes in regulations (Boiral, 2006). Increasingly, different actors across sectors such as political actors, civil society, NGOs, and investors are framing climate change as an opportunity. The most striking feature of business responses to climate change, as reflected in these reports, is their inconsistency, ambiguity, heterogeneity, and limited scope. The heterogeneity in response reflects not only the degree to which a firm is acting, but also which of many possible actions it takes (Jones and Levy, 2007). Further, Chatterji and Toffel (2010) argued that company ratings by other agencies are important to companies because that reduces the information asymmetry between the company top management and various other stakeholders, which in turn, is associated with company's performance. In the case of CDP, it should be more important for a company, because investors are directly involved and the legitimacy of that company can be threatened if negative information is published (Hunter and Bansal, 2007).

Since many of the international agreements including the Kyoto Protocol have led to conflicts of interest between countries, many of the countries did not adopt stricter rules to reduce carbon emissions. This was mainly to avoid companies moving their assets to other less stringent regulatory locations. CDP is focusing on companies and not 
nations, so the conflict between nations is expected not to directly undermine the carbon emission reduction efforts.

The CDP asks top managers of world's largest public companies certain questions that are co-signed by the participating institutional investors to disclose information regarding their climate change related strategies. The information asked includes the risks and opportunities that climate change poses to their companies, what strategies they use to capitalize the opportunities and mitigate the risks, and details of the carbon emissions in their firm. These disclosures are extensive and a large number of MNEs from U.S. are also part of this disclosure project although it is neither a norm nor a requirement for firms in the U.S.

Bansal (2002), based on a study of ISO 14001 standards, suggested that the perceived importance of adopting quality standards by companies is positively related to the perceived performance hurdle. If the internal programs of the companies comply with the external schemes for carbon reduction, those companies will have a competitive advantage over their competitors who have to adapt to their already running programs (Hoffman 2005).

The information on climate change related risks and opportunities shared among the firms through their disclosure reports. The sharing of climate change related concerns, exposures, and opportunities across firms helps firms to better analyze the issue internally among themselves and to come up with effective climate change policies to reduce carbon emissions and improve profitability at the same time (Lash and Wellington, 2007; Carbon Disclosure Project, 2011). The policy makers at national level and supranational 
level are expected to benefit from such disclosure programs involving multinationals that have excellent global reach.

The analysis focuses mainly on the data of CDP, a London-based NGO that represents more than 722 institutional investors with a combined $\$ 87$ trillion in assets under management at the time of publishing the CDP Global Report 2013. The respondents for the survey leading to the CDP Global 500 report for the year 2013 include 81\% of Global 500 companies. "In May, 2002 the Rockefeller Philanthropy Advisors organized the Carbon Disclosure Project, mobilizing \$4 trillion in institutional investors to petition 500 large corporations to quantify their Green House Gas (GHG) emissions” (Hoffman, 2005). Observed in CDP Report 2013, the companies in the report had approximately double the total average return of the Global 500 between January 2005 and May 2013. Sixty eight percent (269) of the Global 500 companies have integrated climate change activities into their overall strategy. The companies reported 1,780 emission reduction activities in 2013 including energy efficiency, low carbon energy installations, and behavioral change.

This dissertation extends Chatterjee and Toffel's (2010) argument on how firms respond to ratings. Since the company's profit and loss is dependent on how important the company's response to CDP is for stakeholders. The evaluation is particularly important because a poorly rated company would be considered risky by the investors because of the possible negative impact on government and on civil society (Delmas and Toffel, 2008). A variety of stakeholders, including environmental activists, will notice if a MNE has a poor environmental rating which in turn could result in conflicts, agitations, law suits (Lenox and Eesley, 2009) and further negative publicity for the MNE. 
Government alone cannot regulate a global situation such as climate change (Ruggie, 2004). Since the Kyoto Protocol came into existence, firms have been increasingly participating with governments and non-governmental organizations in global environmental policy formulation and implementation (Andonova et al., 2009). Another motive of firms participating in environmental programs was to conceal their poor environmental compliance history from monitoring agencies such as the Environmental Protection Agency (Arora and Cason, 1996). Through multiple forms institutional pressure can act upon organizations (Delmas and Toffel, 2012). The voluntary disclosure is strategically important as it is relevant to investors and other stakeholders such as customers, regulators, and NGOs. This is particularly important in an 'investor-driven’ governance network. Griffin et al., (2011) recently studied companies that disclose greenhouse gas emissions through CDP and observed that investors not only rely on the disclosed data but use their own estimates of non-disclosed emission amount as value relevant. So they argued that stock prices reflect greenhouse gas emissions from channels other than CDP disclosure. This would imply that there is likely to be no incentive for the companies not to disclose their greenhouse gas emission details through the CDP. In the case of U.S., prior to the EPA's GHG mandatory Reporting Rule, which became effective December 29, 2009 and requires reporting of carbon emissions for 2010 and thereafter (EPA, 2009), carbon emission disclosures were not required by any national regulatory body in the U.S. A recent proposal by the EPA in June, 2014 to reduce the carbon emission of power plants in the U.S. by 30 percent of the level of 2005 by the year 2030 is an important step in the U.S. as far as governmental policy on climate change is concerned. Even though the steps announced are specifically 
aimed at coal based power plants which are the most carbon polluting enterprises, this is expected to act as a strong signal to businesses to formulate appropriate strategy. The strategic options to use the carbon emission reduction activities in the business process are not equal for all the diverse firms in different industries. The potential to send credible signals to different concerned entities about the viability of carbon emission reduction is essential (Pinkse and Busch, 2013). The investors associated with carbon disclosure project (CDP) force firms to be accountable to disclose (Kolk et al., 2008). Firms are found to proactively respond to regulations in jurisdictions where they do not have any operations (Fremeth and Shaver, 2013). This would indirectly indicate that the other stakeholders like environmental groups, apart from primary stakeholders such as investors, have an influence in the choices that a firm makes. It is likely that the CDP, thus, had an impact on the strategic choices that firms make with regard to carbon emission reduction activities and processes as part of the firm strategy or as the core strategy.

\section{RESOURCE BASED VIEW}

Penrose (1959) recognized that heterogeneity in products and services as a result of firm's resources gives unique advantage to the firm over its competitors. Wernerfelt (1984) conceptualized it later as a resource position barrier that gives a firm advantage over another firm after establishing strength in the existing market. This is relevant for a MNE that is internationalizing to ensure that its unique strengths are harnessed, sustained, and maintained while trying to gain and accomplish new competitive advantages. Barney (1991) explained that the peculiarities that these resources and capabilities need to have 
to provide competitive advantage are value, inimitability, rarity, and non-substitutability by other resources. Thus, the resource-based view assumed that firms are heterogeneous within an industry in regards to their strategic resources and that resources are not perfectly mobile across firms and as a result heterogeneity can be sustained. Accordingly, the competitive advantage lies on firm resource heterogeneity and immobility. Barney's (1991) conception of valuable firm resources was in relation to the external environment where the firm operates so that it can capitalize on opportunities and/or nullify the threats it faces. The external environment is dynamic and evolving and so are the firm's resource strengths and capabilities. In order to meet the challenges posed by climate change, firms have to acquire and complement their resources to get a competitive advantage over competitors. Peteraf (1993) emphasized four cornerstones of competitive advantages: heterogeneity of resources among competitors, imperfect mobility of strategic resources, ex ante limit to competitors of these assets, and ex post limits to competition. Once these criteria are met, competitive advantage results and the ability of the firm to implement a strategic resource superiority results in firm performance. Managerial resources and capabilities in the form of top management are crucial in generating rents as top management is immensely valuable and hard to imitate (Castanias and Helfat, 1991). Grant (1991) extended this view by focusing on intangibility of assets. Amit and Schoemaker (1993) conceptually tried to highlight how firm specific resources can add to competitive advantage within changing strategic industrial factors dependent on multiple influences. They introduced the concept of strategic industry factors that are dynamic and varying. Each firm with managers behaves with ambiguity and often arrives at suboptimal choices trying to align strategic assets in tandem with strategic industry 
factors to get a competitive advantage. So there will be an attempt to align the firm resources and capabilities to the changing strategic industrial factors and manager's decision making process. Organizational structure and processes contribute to the effectiveness of how a firm becomes successful. Thus, managerial and organization behavior and decision making are also added to the potential resources and capabilities that lead to the competitive advantage of a firm. The authors explain the characteristics of strategic assets that are inimitable, complementary, non-substitutable, low tradable, appropriable, more firm-specific, durable, and scarce to provide competitive advantage to the firm. The strategic assets decisions were examined throughout in light of resource market imperfections, bounded, and variable rationality within and across the firms. Prahalad and Hamel (1990) conceptualized core competency which is distinctive expertise that a firm develops over a period that is critical for its long-term growth. The core competencies have to dynamically evolve and adapt to the new situations that the external environment of the firm provides. In the context of environmental capabilities development as a core competence, climate change challenge provides firms with a huge challenge to develop new core competence. Dierickx et al. (1989) suggested that markets for many strategic assets such as reputation did not exist and these assets are strategic to the firm to the extent the assets are not tradable, not imitable, and not substitutable.

The fit between what a firm is capable of doing with respect to the opportunities available is an important aspect of the resource-based view framework (Russo and Fouts, 1997). Hart (1995) proposed the natural-resource-based view (NRBV) of the firms as a framework to explain that companies have three key strategies, i.e., (i) pollution prevention practices/waste management, (2) product stewardship, a focus on the 
reduction of waste at every stage of the product's life cycle, and (3) sustainable development which is producing and consuming products that are sustainable with the environment. Aragon-Correa and Sharma (2003) extended Hart’s framework where they argued that the general business environment has an important role in the development and effectiveness of a proactive environmental strategy. Climate change is challenging businesses to sharpen its environmental capabilities and to cater to the needs of the new external environment. Christmann (2000) empirically tested Hart’s (1995) ideas and found that the interactions between environmental strategies and the firm's heterogeneous, unique assets lead to cost advantages for the firm. By developing superior environmental capabilities that capitalize the external opportunities, a firm improves its international competitive position (Aguilera-Caracuel et al., 2012). Rugman and Verbeke (1998a, b) argued that firm-specific advantages along with country-specific advantages determined the environmental strategy that a firm would follow. Developing 'green' environmental capabilities or 'green' firm-specific advantages is important for a firm to address a serious environmental issue such as climate change while remaining profitable (Kolk and Pinkse, 2008). To implement a proactive environmental strategy and to develop environmental capabilities necessitates huge investment by firms (Christmann and Taylor, 2011). Developing superior environmental resources and capabilities by MNEs is also dependent on home country environmental standards (Porter and van der Linde, 1995). 


\section{CHAPTER III THEORETICAL DEVELOPMENT AND HYPOTHESES}

In the emerging market context, Peng et al. (2009) proposed an institution based “tripod” approach to considering firm strategy, particularly international business strategy that considers institutions as well as industry and resources. The tripod of firm strategy includes "industry-based competition, firm-specific resources and capabilities, and institutional conditions and transitions”. This dissertation uses a similar approach. The comparison of environmental performance/capabilities of global and regional-oriented firms primarily focuses on the firm specific capabilities, because the global oriented firms’ capabilities and resources are expected to differ from that of the regional oriented firms. By focusing on the effect of industry type on environmental performance of MNEs and their possible difference in association with MNE orientation, the difference in the degree of relationship on the environmental capabilities/performance of firms based on their industry is also assessed. The third part of the tripod, i.e., institutions, is focused in this dissertation using two parts: a) effect of environmental institutional distance in the relationship between global and regional-oriented MNEs and their environmental performance, and b) differences in performance for MNEs originating from the institutionally different European Union and the U.S. The conceptual model of the study also supports the suggestion of Sethi and Elango (1999) and Ricart et al. (2004) that factors affecting firms in the global arena include resources of the firms, the structure of the industry in which the firm operates, and home country factors. 
Figure 1: Conceptual model of the study

\section{Basic Model:}

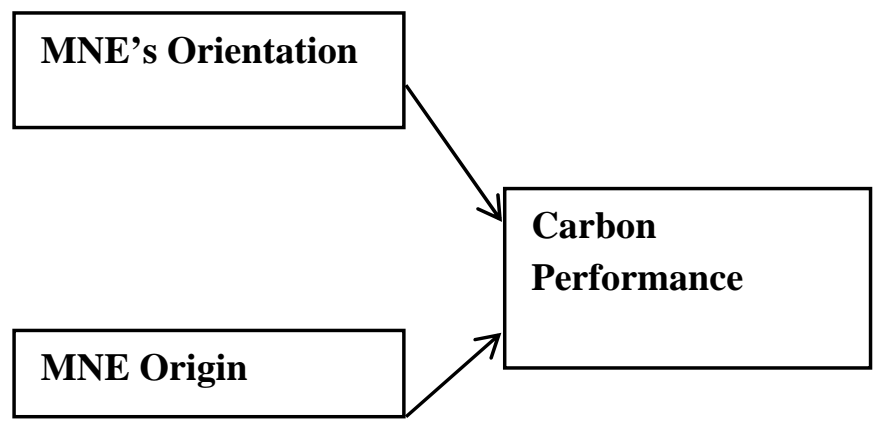

\section{Model with Hypotheses:}

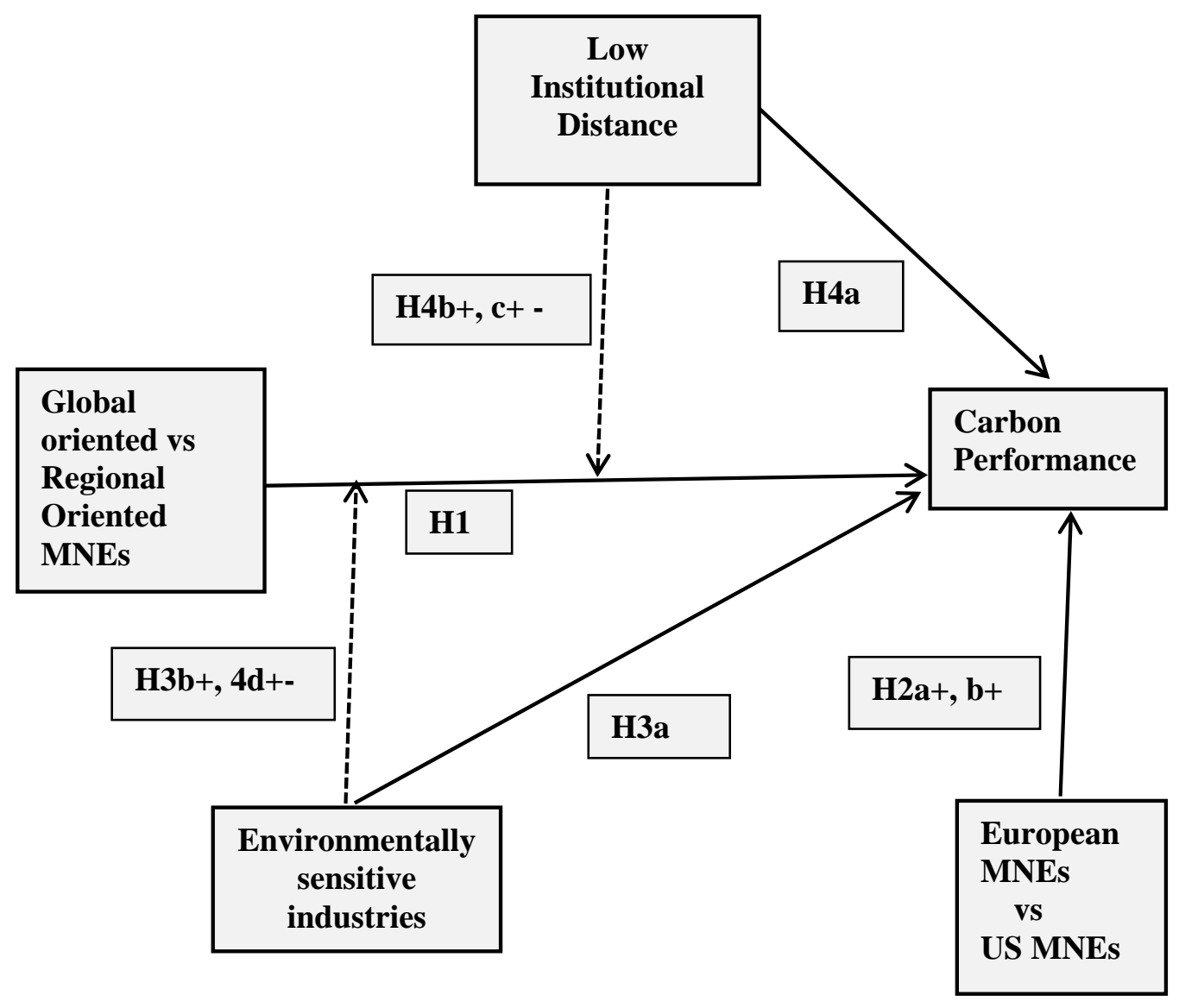


In order to propose the first hypotheses, this dissertation uses the Resource Based View (RBV). The RBV as a theoretical lens was earlier used to study the relationship of regionalization and firm performance by Qian et al. (2008). The fit between what a firm is capable of doing with respect to the opportunities it has is a major focus of RBV (Russo and Fouts, 1997). The environmental strategy has recently become a fundamental aspect of the multinational strategy as discussed in the literature review. Understanding the relationship between resources and capabilities in attaining a competitive advantage and profitability is one of the fundamental aspects of strategy formulation.

Capabilities and resources that direct a firm’s development and environmental capabilities for competitive positioning are becoming a core part of firm strategy (Hoffman, 2005; Enkvist et al., 2008). Grant (1991) suggested that RBV predicts the direction of firm performance as: firm's resources lead to capabilities, then capabilities lead to competitive advantage which leads to firm performance. However, in order to achieve a sustained competitive advantage firms should have valuable, rare, imperfectly imitable, and non-substitutable resources [VRIN] (Barney, 1991). Firms may gain advantage over their competitors by developing resource position barriers so that new firms take time to gain customer loyalty, production experience, and technological leads (Wernerfelt, 1984). This is supported by Hart's NRBV (1995) where the emphasis is on the "constraints and opportunities provided by the environment" by the influence of external stakeholders in moving a firm towards sustainable growth. This could mean that external stakeholder demand would decide when the unique resources a firm is trying to acquire would be valuable and inimitable (Russo and Fouts 1997). Firms that have operations in markets dispersed across the world are more likely to face different 
challenges and opportunities and a more daunting task of managing and possibly integrating their operations. Based on this idea, this dissertation argues that the external environment will have a greater say in the case of global-oriented firms than for the regional oriented firms.

Climate change strategy has given firms a great opportunity to gain a sustainable competitive advantage. Goldman Sachs Report (2009) assessed the performance of 800 global companies with an average market cap of USD \$3 billion and observed that there are significant differences in companies taking action for climate change performance. Those companies that are adept at reducing their greenhouse gas (GHG) emissions by changing products and or processes, developing new management skills or technologies to produce less greenhouse gas, and trading in emission credits will find an advantage in the climate change market (Hoffman, 2005). It is also suggested that competitors, suppliers, buyers, consumers, investors, and government adopt GHG reductions either because they operate in ratified regions or because they see a proactive stance in GHG reductions as sound business strategy.

Sustainability has become a philosophy reflecting broader social and economic development (Bartlett et al., 2008). The environmental policy and strategy of the firm has a significant influence on its gaining legitimacy (Bansal, 2005), and the legitimacy of the firm, in turn, strengthens the social and economic goals of the firm. In the context of climate change, Pinkse and Kolk (2012) recently argued that it is difficult for multinationals to address the global issue of climate change on a country-by-country basis. Global-oriented firms have their resources dispersed across the world or they need to distribute the resources across the world. In both the cases integrating their resource 
capabilities is very important. Hence, it is expected that the integration of carbon reducing activities as a strategic-fit (Hoffman, 2005) would be different for firms with regional orientation versus those with global orientation (Banalieva and Sarathy, 2010). This dissertation argues that firms that are global-oriented will have a higher need for gaining legitimacy and also better resource deployment capabilities for the execution of environmental strategy across the operating locations.

Another demand for legitimacy comes from the very fact of a firm's being a global-oriented one. In this era of globalization, where multinationals are expected to be carriers and distributors of value, in order to reduce the opposition (Stiglitz, 2002) to globalization, multinationals are expected to be cautious when adopting a global strategy. Evidence shows that MNEs with global orientation are likely to use more environmentally friendly practices compared to regional oriented MNEs (Transnational Corporations, UNCTAD 2011). This observation is supported by Aguilera-Caracuel, et al. (2012) when they suggested that multinationals "benefit from higher environmental standards in their home market because such standards induce them to develop superior environmental management capabilities, which improve an MNC’s international competitiveness".

There are firm-level differences in capabilities, over and above the differences due to industrial influences on social issues, depending upon the firm's competitive positioning (Porter and Kramer, 2006). Firm-specific advantages (FSAs) that are advantages specific to the firm regardless of its location (Rugman and Verbeke, 1992) with respect to environmental capabilities could be expected to be more pertinent for global-oriented firms than that for regional-oriented firms as the former can standardize 
their competence across the countries, thus improving the efficiency of governance. Standardization is likely to enable the global-oriented multinationals to have lower cost, better management, and more effective utilization of their environmental strategies, especially with regard to an environmental concern of global dimension such as climate change. Advanced environmental capabilities also improve an MNC's competitiveness across nation borders (Aguilera-Caracuel, et al., 2012). The importance of a global environmental standard is reflected in higher market values as measured by Tobin's q, comparing high performing firms to firms defaulting to less stringent or poorly enforced host country standards (Dowell et al., 2000). This indicates that the firm with superior environmental resources have an incentive to standardize its capabilities across nation borders. Therefore, better environmental performance in the form of carbon emission reduction strategy requires breaking the dominant logic (Prahalad, 2005) of the firm as the climate change strategy is a recent phenomenon. This would mean firms should have core competencies to use for producing innovative products for competitive advantage (Prahalad and Hamel, 1990). In the context of climate change, carbon friendly innovative products are an important means to capitalize on the opportunity for the firm to break the dominant logic. The global-oriented firms are likely to have better resources, capabilities, and market opportunities to profit from the innovation through the scale and scope of their global outreach. Therefore, global-oriented MNEs are likely to successfully combine cross-country operational knowledge to develop competitive capabilities and advantages that are difficult to replicate by other MNEs (Husted and Allen, 2006; Martin and Salomon, 2003) 
The transfer of the valuable capabilities by MNEs within their internal networks (Bartlett and Ghoshal, 1989) is likely to influence their competitive advantage in the case of the firm's climate change strategy. These environmental capabilities will be increasingly essential for the competitive advantage of the firms (Hart and Dowell, 2011). The valuable, rare, inimitable and imperfectly substitutable resources, apart from providing competitive advantage, will also act as resource position barriers (Barney, 1991; Wernerfelt, 1984) and are likely to help global-oriented multinationals more than the regional-oriented multinationals, as global-oriented multinationals can complement 'resource barriers' with entry barriers in different markets when developing new business models. One of the high salience factors of climate change impact is that early change in business models might be a source of competitive advantage (Delmas and MontesSancho 2010; Kolk and Mulder, 2011). Companies may build or enhance firm-specific advantages based on their country-specific advantages on climate change and the transferability of firm-specific advantages across locations would depend upon whether the latter is location bound or not (Kolk and Pinkse, 2008). Increased multinationality would allow flexibility in acquiring, allocation of resources, scope, and scale efficiency along with learning and knowledge transfer opportunities from diverse market environments (Kennelly, 2000; Kirca et al., 2012). Therefore,

Hypothesis 1: MNEs with global orientation will outperform MNEs with regional orientation on carbon performance ceteris paribus. 
The potential market growth provided by countries differs because of the differences in inherent country-level properties and these differences between countries do not diminish substantially even with the phenomenon of globalization (Tong et al., 2008). These country effects are important for firm performance (Makino et al., 2004). High environmental standards in a home country will result in superior environmental capabilities for MNEs and this will help improve international competitiveness when other countries raise their environmental standard (Porter and van der Linde, 1995). However, the properties of the operational conditions of MNEs are equivocality, ambiguity, and complexity. This results in a unique 'institutional story' for each MNE regardless of whether they operate under similar or different institutional pressures (Kostova et al., 2008). The ability of MNEs to be an efficient vehicle of cross-border transfer of green best practices (Christmann, 2004) to fill the institutional voids by leveraging expertise built up in other contexts (Kolk, 2010; Verbeke, 2010) will be influenced by home and host country of the MNE.

Sethi and Elango (1999) emphasized the role of 'country of origin effect' based factors in shaping the strategic choices and operational modes of multinationals. Carbon intensive industries such as oil and automobile sectors had their firms' strategic responses significantly determined by their institutional environment (Levy and Kolk, 2002; Levy and Rothenberg, 2002; van deWateringen, 2005). Governments can affect decision making of MNE in such a way as to not alter its strategic fit, or, in some cases, its policies encourage firms to alter strategies like exporting or off-shoring instead of importing or producing domestically (Murtha and Lenway, 1994). Without a regulatory framework on climate change debate, firms will not get clear signals on how to behave in 
that market (North, 1990). Immediately after the Montreal Protocol (1987), U.S. companies, unlike their European counterparts, actively challenged climate science in reducing the ozone depleting substances as industrial countries were mainly targeted (Jones and Levy, 2007). There can be a potential liability of origin (Ramachandra \& Pant, 2010), where in a global context, a multinational's 'green reputation' tends to be enmeshed with the political stance of their home country (Dunning \& Lundan, 2008). The difference between U.S. and Europe has been pointed out by Stewart (1993) where he mentioned that most environmental groups and much of the industry, along with many politicians in the U.S., believed that more stringent U.S. regulatory standards results in significant competitive disadvantage for the nation. The implementation of ISO 14000 was done by relatively few firms in the U.S. as compared to their counterparts in Europe which was due to the institutional differences between U.S. and Europe in encouraging the certification process. There was also considerable variation in the national regulatory responses on climate-change, with European Union coming up with European Union emission trading scheme (EU ETS) while U.S. rejected the Kyoto Protocol (1997). According to DiMaggio and Powell (1983), multinationals tend to be isomorphic in order to abide by the institutional requirements of the country. So the MNEs originating from the European Union would have to develop environmental capabilities that conform to the institutional requirements of their home country. Therefore,

Hypothesis 2a: MNEs from European Union will have better carbon performance compared to MNEs from U.S. ceteris paribus. 
However, Hoffman $(1999 ; 2005)$ have argued that without any regulatory pressure in home-country in regard to climate, many US MNEs took strategic choices to capitalize the external situation proactively through strategies to innovate in this regard. Further, forward looking firms expect that regulations in other jurisdictions can be adopted at the home country, constraining their businesses and opening them up to greater competition in either product market or in resource market affecting firm performance (Fremeth and Shaver, 2013). The main opposition to adopting climate related standards as a business norm in the U.S. is that it will make MNEs from U.S. incur higher cost and undermine the competitive advantage against MNEs from other countries that do not abide by the carbon standards and follow a climate strategy. Environmental regulations, in general, except climate change regulations, are traditionally very stringent in the U.S. and hence this institutional context has helped MNEs from U.S. develop 'green competencies' (Rugman, 1998). It should, therefore, be quite easy for MNEs from the U.S. to develop, acquire, and encourage 'carbon competencies'. Therefore, with regard to climate change, MNEs from U.S. are likely to pursue a proactive, positive strategy that drives innovation and firm performance. Hence,

Hypothesis 2b: MNEs from U.S. will have better carbon performance compared to MNEs from European Union ceteris paribus.

Christmann (2004) showed that multinationals deal with a complex global context in standardizing environmental policies. The author argued that industry pressure leads to environmental policy standardization in a multinational; firms try to enhance their 
legitimacy by copying their successful competitors. The value of resources varies with industry and time (Collis and Montgomery, 1995) and hence industry can be expected to influence the resource utilization of the multinationals. Further, depending on the institutional context an industry operates, the technological strategies of a firm in a specific industry may differ because of likely differences in the sociopolitical legitimization process (Hall, et al., 2014).

The multinationals face pressure for local responsiveness and for global integration, the exogenous factors that multinationals has to adapt to (Birkinshaw et al. 1998) and the relationship between global integration and performance may vary substantially from one industry to another (Birkinshaw et al., 1995). The same industries tend to be similar and different industries tend to be dissimilar because of market peculiarities and pressures for operational conformity (Sethi and Elango, 1999). This would imply that global integration of environmental capabilities is likely to be influenced by the requirements and incentives that an industry provides. Recently, in the Emission Trading Scheme (ETS) of European Union, objectives to curtail surplus carbon dioxide emissions were watered down in response to lobbying from energy-intensive industries (UNCTAD report, 2011). Berchicci et al. (2012) found that environmental performance affects corporate strategy and does so in different ways for clean firms visa-vis dirty firms. Similarly difference between industries is obvious as the impact of India's green rating project was different for dirty and clean plants (Powers et al, 2011).

There are differences in environmental capabilities and expectation of performance and real performance across different environmentally sensitive or insensitive industries. Cho and Patten (2007) observed that firms in environmentally 
sensitive industries were more likely to disclose some type of environmental information such as expenditure on pollution control through their annual reports and/or websites. The environmentally sensitive industries are expected to have better performance as compared to other industries because of high visibility of their environmental polluting activities. This point is supported by (Goldman Sachs Report, 2009, Figure 2), when they observed the effectiveness of response to climate change to vary across industries and to have created opportunities and competitive advantage that were important for investment performance. The report also highlighted that the proportion of companies taking active steps is high in carbon intensive sectors compared to the companies in the less carbon intensive sectors. The finding is substantiated by Kolk and Mulder’s (2011) finding that high-salience industries (such as oil and gas, automobiles, and utilities), when confronted with climate change regulation had issues as their core activities in fossil-fuel based business models were threatened. Greenhouse gas intensive industries such as utilities, energy, and materials had companies whose valuation of stock price by investors were more negative than for other industries (Griffin et al., 2011). These industries have difficulty reducing their carbon emissions in the short run, because that would require a major revamp of their core assets and processes (Kolk and Pinkse, 2008). Therefore,

Hypothesis 3a: Industry type will be associated with carbon performance.

Hypothesis 3b: Industry type will be associated with MNE orientation and carbon performance such that MNEs in environmentally sensitive industries will have better carbon performance compared to non-environmentally sensitive industries. 
The motivations for a multinational to go abroad are determined by the host country conditions of the markets that are targeted (Galan, Gonzalez-Benito and ZuñigaVicente, 2007). Since multinationals have their own institutional profile regardless where they are operating, they need to gain legitimacy in all the host countries in which they are operating or targeting to move (Kostova and Zaheer, 1999). Since organizations are embedded within the general industry and institutional conditions and pressures where they operate (Delios, 2010), naturally the similarity of institutions becomes one of the important factors to influence the strategy of the firm. The degree of similarity of institutions between two or more countries is reflected in institutional distance between home and host countries (Kostova and Roth, 2002).

Based on the strategies of firms participating in the Climate Challenge program (participating years 1995-2000), Delmas and Montes-Sancho (2010) showed that late joiners and early joiners within the voluntary agreements adopt different strategies because they face different institutional pressures. Aguilera-Caracuel et al. (2012) showed that the environmental institutional distance between the home and the host country, and the headquarter's financial performance have an impact on the environmental standardization decision in multinational companies. Aguilera-Caracuel et al. (2012) have highlighted the limited attention of the role of institutional distance and environmental issues, especially when institutional pressures have increasingly compelled multinationals towards embracing corporate social responsible activities (Sharfman et al., 2004). As the distance from the home country increases, with its regulatory/institutional, cultural and economic components, the non-location bound FSAs 
become subject to decay (Rugman and Verbeke 2008). Narrowing of institutional distance between societal actors and firms would happen if the results of the corporate sustainable development measurements are given to the organizational stakeholders (Bansal, 2002), i.e., investors associated with the carbon disclosure project. We, therefore, expect that institutional distance has an influence on the firm performance as distance also influences managerial decision-making which is the center point of the firm’s strategic decisions.

Hypothesis 4a: Institutional distance will be associated with carbon performance.

Hypothesis 4b: Institutional distance will be associated with MNE orientation and its carbon performance such that MNEs with low institutional distance will have better carbon performance compared to those with high institutional distance.

From the discussion, institutional distance is indirectly related to carbon performance. The firms that are highly internationalized are more likely to face different institutional pressures compared with the firms that are less internationalized. Global-oriented MNEs are more likely to be dispersed all over the globe and hence institutional distance of global-oriented MNEs is likely to be higher than that of regional-oriented MNEs. Since institutional diversity warrants global-oriented MNEs to abide by different rules and regulations and at the same time be under scrutiny of several NGOs and other agencies, they are likely to give adequate attention to be environmentally proactive in those industries where visibility is high. Previous research suggests that MNEs in the service 
sector having a higher degree of home-region orientation than those of MNEs in the manufacturing sector (Rugman and Verbeke, 2008), implying that MNE-orientation is related to industry type also. Therefore,

Hypothesis 4c: The effect of institutional distance on carbon performance will be different for global-oriented versus regional-oriented MNEs.

Hypothesis 4d: The effect of industry type on carbon performance will be different for global-oriented versus regional-oriented MNEs. 


\section{CHAPTER IV METHODOLOGY}

\section{SAMPLE AND DATA SOURCES}

The public database of the carbon disclosure project (CDP) in their website (https://www.cdp.net/en-us/pages/about-us.aspx) is described as 'the largest collection globally of self-reported climate change, water and forest-risk data.' The main sample consists of Global 500 firms that are part of the carbon disclosure program. The data on carbon performance index is from the reports published by the CDP, a London-based NGO that represents more than 722 institutional investors with a combined \$87 trillion in assets under management. The carbon performance data was found available from the year 2010 through 2013. This is voluntary disclosure information, and carbon emission reduction and climate change strategy as well as the associated measuring mechanism is evolving. Therefore, the sample from the recent CDP reports is considered to reflect reality better and hence this dissertation will focus mainly on the latest years for the empirical analysis. To that extent, this report can be considered as a convenience sample. In order to observe the general trends and patterns, all four years, from 2010 through 2013, are used. However, for conducting logistic regression analysis for the effect of firm-orientation and firm's home country effect on carbon performance, this dissertation uses the data from the years 2011 through 2013 for the reasons explained under the subheading logistic regression. The analysis of the CDP report is expected to, however, provide a greater understanding of the real process on climate strategy that is happening in the business sector, where ambiguity in policies across the nations exist. 
The firm-level and segment level data are supplemented by Compustat Global and Bloomberg. In addition, the annual reports of firms and ORBIS, and SEC filings were used to get affiliate level data.

\section{CDP REPORTS}

A total of 500 firms participated in the CDP over the years 2010 through 2012 and in 2013, 404 firms participated. Eighty-one percent of the companies listed on the Global 500 companies participated in the CDP in the year 2013. However, this is a smaller number of companies than those participating in previous years. The possible reasons for reduction in the number of companies participated in the CDP survey will be discussed in the discussion section. One of the observations that the CDP survey report highlights is that there is consensus among corporate businesses to acknowledge accountability and transparency regarding carbon emission activities and climate change policies. The CDP reports mentions that businesses interest is reflected in the fact that the quality of disclosed information has increased over the years.

Table 1: Industry wise, number of firms participated in the CDP

\begin{tabular}{llrrrr}
\hline & Industry/Year & 2013 & 2012 & 2011 & 2010 \\
\hline 1 & Consumer Discretionary & 47 & 60 & 56 & 46 \\
2 & Consumer Staples & 47 & 45 & 37 & 44 \\
3 & Energy & 40 & 57 & 53 & 54 \\
4 & Financials & 97 & 111 & 157 & 119 \\
5 & Healthcare & 30 & 38 & 0 & 35 \\
6 & Industrials & 40 & 49 & 55 & 53 \\
7 & Information Technology & 29 & 38 & 39 & 40 \\
8 & Materials & 35 & 42 & 47 & 42 \\
9 & Telecommunication & & & & \\
& Services & 22 & 30 & 29 & 32 \\
10 & Utilities & 17 & 30 & 27 & 35 \\
\hline & Total Firms & 404 & 500 & 500 & 500 \\
\hline
\end{tabular}


Table 1 provides the total firms in the CDP report for each of last four years. There are firms that do not fall under any of the six performance categories (A, A-, B, C, $\mathrm{D}$, and $\mathrm{E}$ ) in the CDP reports. Table 2 shows that the proportion of firms falling under one of the six performance categories A through E, increased from 63 percent in the year 2010 to approximately 91 percent in the year 2013. One plausible reason is that by 2013, many firms that are not serious of climate change strategy did not participate in the survey even though absolute number of firms falling under the performance category decreased in 2013.

Table 2: Proportion of firms in each performance categories (A to E)

\begin{tabular}{lrrrr}
\hline Years/Number of MNEs & 2013 & 2012 & 2011 & 2010 \\
\hline Total in the CDP report & 404 & 500 & 500 & 500 \\
Total in performance ratings (A through E) & 367 & 347 & 339 & 315 \\
Percentage to total firms & $(90.8)$ & $(69.4)$ & $(67.8)$ & $(63.0)$ \\
\hline
\end{tabular}

Table 3 shows the distribution of firms under different performance categories industry wise through the years 2011-2013. The year 2010 was omitted because the performance data for that year was in the process of improvement and therefore for the final analysis, the data for the three consecutive years 2011-2013 was used. The financial sector is predominant in all the performance categories. The possible reasons are analyzed under the discussion section. As expected, for a new global environmental concern, carbon performance, firms were found to concentrate at the lower performance groups of $\mathrm{B}, \mathrm{C}$ and $\mathrm{D}$, while $\mathrm{E}$ had a lower percentage of firms compared to that of the carbon performance category of A-. The carbon performance category B had the highest number of firms constituting $36.8 \%$ of total firms. Another interesting observation is that 
while the financial sector had a large number of firms in the high carbon performing category, the energy and utilities sectors which are more visible and carbon intensive had fewer firms.

Since Table 3 lists the industry-wise distribution of all the firms for all the three years 2011, 2012, 2013, it may not reflect the trends over the years. To highlight this point, Table 4 is provided for the last year 2013. Interestingly, there is not any firm from Information Technology and Telecommunication Services under the carbon performance category 'A-'. Under the performance category 'B', all the industrial sectors had more or less the same number of firms except the Information Technology sector which had the lowest. This observation for the year 2013 differs when we look at the data for 2011-2013 in Table 3, where Information Technology sector is not the lowest.

Table 3: Industry wise, firms under different carbon performance categories

\begin{tabular}{|c|c|c|c|c|c|c|c|}
\hline \multirow[t]{2}{*}{ Industrial Sector } & \multicolumn{2}{|c|}{$\begin{array}{r}\text { High Carbon } \\
\text { Performers } \\
\end{array}$} & \multicolumn{4}{|c|}{ Low Carbon Performers } & \multirow{2}{*}{ Total } \\
\hline & A & A- & $\mathrm{B}$ & $\mathrm{C}$ & $\mathrm{D}$ & $\mathrm{E}$ & \\
\hline \multirow[t]{2}{*}{$\begin{array}{l}\text { Consumer } \\
\text { Discretionary }\end{array}$} & 14 & 6 & 40 & 27 & 25 & 5 & 117 \\
\hline & $(11.7)$ & $(13.0)$ & $(10.3)$ & (9.9) & $(15.1)$ & $(8.5)$ & $(11.1)$ \\
\hline \multirow[t]{2}{*}{ Consumer Staples } & 12 & 7 & 48 & 26 & 13 & 2 & 108 \\
\hline & $(10.0)$ & $(15.2)$ & $(12.4)$ & $(9.5)$ & $(7.8)$ & (3.4) & (10.3) \\
\hline \multirow[t]{2}{*}{ Energy } & 4 & 3 & 34 & 33 & 19 & 6 & 99 \\
\hline & (3.3) & (6.5) & (8.8) & $(12.0)$ & (11.5) & $(10.1)$ & $(9.4)$ \\
\hline \multirow[t]{2}{*}{ Financials } & 43 & 9 & 84 & 71 & 43 & 19 & 269 \\
\hline & $(35.8)$ & $(19.6)$ & $(21.7)$ & (25.9) & $(25.9)$ & $(32.2)$ & $(25.6)$ \\
\hline \multirow[t]{2}{*}{ Healthcare } & 4 & 3 & 29 & 10 & 10 & 3 & 59 \\
\hline & (3.3) & $(6.5)$ & $(7.5)$ & (3.7) & (6) & (5.1) & (5.6) \\
\hline
\end{tabular}




$\begin{array}{lrrrrrrr}\text { Industrials } & 10 & 8 & 29 & 35 & 20 & 3 & 105 \\ \text { Information } & (8.3) & (17.4) & (7.5) & (12.8) & (12.1) & (5.1) & (10.0) \\ \text { Technology } & 15 & 2 & 29 & 17 & 13 & 7 & 83 \\ & (12.5) & (4.4) & (7.5) & (6.2) & (7.8) & (11.9) & (7.9) \\ \text { Materials } & 7 & 6 & 40 & 29 & 8 & 9 & 99 \\ & (5.8) & (13) & (10.3) & (10.6) & (4.8) & (15.3) & (9.4) \\ \text { Telecommunication } & 5 & 0 & 25 & 14 & 9 & 5 & 58 \\ \text { Services } & (4.2) & (0) & (6.4) & (5.1) & (5.4) & (8.5) & (5.5) \\ & 6 & 2 & 30 & 12 & 6 & 0 & 56 \\ \text { Utilities } & (5.0) & (4.4) & (7.7) & (4.4) & (3.6) & (0) & (5.3) \\ & 120 & 46 & 388 & 274 & 166 & 59 & 1053 \\ \text { Total } & (11.4) & (4.4) & (36.8) & (26) & (15.8) & (5.6) & (100) \\ & & & & & & & \end{array}$

Figures in parentheses are percentage to Total (1053); years 2011-2013

Table 4: Industry wise, firms under different carbon performance categories (2013)

\begin{tabular}{|c|c|c|c|c|c|c|}
\hline Industry/Performance & A & A- & $\mathrm{B}$ & $\mathrm{C}$ & $\mathrm{D}$ & $\mathrm{E}$ \\
\hline Consumer Discretionary & 8 & 5 & 14 & 9 & 6 & 2 \\
\hline Healthcare & 1 & 3 & 15 & 5 & 4 & 1 \\
\hline Industrials & 5 & 4 & 15 & 8 & 3 & 0 \\
\hline Information Technology & 9 & 0 & 8 & 4 & 5 & 0 \\
\hline Materials & 3 & 2 & 15 & 9 & 4 & 0 \\
\hline Telecommunication Services & 3 & 0 & 12 & 2 & 3 & 0 \\
\hline Utilities & 2 & 0 & 13 & 1 & 1 & 0 \\
\hline Total & 57 & 22 & 161 & 81 & 38 & 8 \\
\hline
\end{tabular}

Table 5 provides information on the number of companies falling into each performance category with the proportion based on total firms in the CDP report of that particular year. The proportion of firms falling under performance category ' $E$ ' has 
decreased over the years, while firms falling under performance category ' $\mathrm{D}$ ' has shown an overall increase over the years except for 2013. The performance category 'C' shows more or less a stable proportion of firms. Performance category 'B' shows that the overall proportion of firms falling under it has increased in 2013 as compared to 2010.

Performance category 'A-' has more or less same percentage firms falling under it for the years 2011 and 2013. Interestingly, however, performance category 'A-'do not have any firms in 2010 and 2012. Performance category 'A' has shown a substantial increase in the proportion of firms.

Table 5: Performance of firms as a proportion to the total firms

\begin{tabular}{lccccccc}
\hline Year/Performance & $\mathrm{A}$ & $\mathrm{A}-$ & $\mathrm{B}$ & $\mathrm{C}$ & $\mathrm{D}$ & $\mathrm{E}$ & Total \\
\hline 2013 & 57.00 & 22.00 & 161.00 & 81.00 & 38.00 & 8.00 & 404 \\
& $(14.1)$ & $(5.5)$ & $(39.9)$ & $(20.1)$ & $(09.4)$ & $(2.0)$ & $(100.0)$ \\
2012 & & & & & & & \\
& 34.00 & 0 & 136.00 & 86.00 & 69.00 & 22.00 & 500 \\
& $(6.8)$ & 0.00 & $(27.2)$ & $(17.2)$ & $(13.8)$ & $(04.4)$ & $(100.0)$ \\
2011 & & & & & & & \\
& 29.00 & 24.00 & 91.00 & 107.00 & 59.00 & 29.00 & 500 \\
& $(5.8)$ & $(4.8)$ & $(18.2)$ & $(21.4)$ & $(11.8)$ & $(05.8)$ & $(100.0)$ \\
2010 & & & & & & & \\
& 48.00 & 0 & 155.00 & 102.00 & 10.00 & 0 & 500 \\
& $(9.6)$ & 0 & $(31.0)$ & $(20.4)$ & $(2.0)$ & $(0.0)$ & $(100.0)$ \\
\hline
\end{tabular}

Total implies total firms in All categories in each year of consideration

Parentheses is percentage of firms in that year with respect to the total firms for that year

\section{MEASURES}

\section{DEPENDENT VARIABLE: CARBON PERFORMANCE.}

In their approach of 'organizational greening' Hunt and Auster (1990) classified environmental strategy into different stages. They detailed developmental stages through which firms can progress and they emphasized the contrast between relatively superior 
environmentalism and a deeper, a more encompassing approach that indicates proactiveness and voluntary leadership. Schot and Fischer (1993) also made a distinction between compliance driven firms and firms that adopt more proactive environmental strategies. The same is reflected in Roome's (1992) model of environmental strategy that contrasts “compliance-oriented” with “compliance-plus” organizations that can be considered equivalent to compliance and proactive strategy. A similar conception is found in Bartlett and Ghoshal’s (1989) classification of multinational-stakeholder relationship into responsive, transformative, exploitive, and transactional in nature. Further, this implies that corporations have to go through the value web as mentioned by Elkington (2004) where different firms are at various stages at a specific time.

The definition for environmental performance used in this study is based on the definition given by Walls et al. (2012). Walls et al. (2012) defined “environmental performance as the result of a firm's strategic activities that manage its impact on the natural environment.” This dissertation measures environmental performance as the extent to which climate change strategy is integrated driving into mature climate change initiatives. These activities or initiatives can vary substantially from proactive approaches that require firms to build and integrate specific capabilities and resources to reactive solutions that minimally meet regulatory standards or ceremonial adoption (Hart, 1995; Kostova and Roth, 2002).

The dependent variable is the carbon performance index, a categorical variable, which indicates the implementation of carbon emission activities and processes into the business systems. In the CDP report, performance was grouped into six categories: A, A-, B, C, D, E. The first two groups have either integrated climate change strategy fully or 
partially and considers it as priority. So in this dissertation, firms coming under the first two groups of A and A- categories are combined and considered as high performing firms, and the firms coming under the remaining categories are classified as low performers. "The performance score assesses the level of action, as reported by the company, on climate change mitigation, adaption and transparency. Its intent is to highlight positive climate action as demonstrated by a company’s CDP response. A high performance score signals that a company is measuring, verifying, and managing its carbon footprint, for example, by setting and meeting carbon reduction targets and implementing programs to reduce emissions in both its direct operations and supply chain” (CDP report, 2011).

\section{INDEPENDENT VARIABLE: MNE ORIENTATION}

The foreign sales to total sales percentage had significant positive association with all dimensions of social performance while other measures of multinationality had relative weak relationship (Kennelly, 2000). The independent variable of this study is the extent of foreign sales outside the home region of the MNE as a proportion to its total sales (regional or global orientation of MNEs) of the multinationals (Rugman and Verbeke, 2004, Rugman and Oh, 2010). The independent variable is a dummy that takes on a value of 1 if the orientation is global and 0 if the orientation is regional. For the purpose of this study, if the home region sales are less than or equal to 50 per cent of the total sales, the firms are considered to have global orientation; otherwise they are considered to have regional orientation. Data was obtained from Compustat Segments database and Bloomberg. 


\section{INDEPENDENT VARIABLE: EUROPEAN OR US MNE.}

Another independent variable of this study is a dummy variable taking value of 1 if the MNE is headquartered in European Union and 0 if the headquarter is in U.S.

\section{INDEPENDENT VARIABLE: INDUSTRY TYPE.}

MNEs in environmentally sensitive industries face stricter regulatory scrutiny and are more likely than firms in non-environmentally sensitive industries to publicly disclose to CDP (Reid and Toffel, 2009). The business models of MNEs in the high salience carbon industries have direct effect on climate change (Kolk and Mulder, 2011). Based on Cho and Patten's classification (2007), the firms are distinguished into that operate in environmentally sensitive industries which include firms in the auto and transport, integrated oils, utilities and other energy industrial sectors to be coded as ' 1 '. For other firms in consumer discretionary, consumer staples, financial services, health care, materials \& processing, producer durables, technology, and other industrial sectors to be coded as ' 0 '. They are christened as non-environmentally sensitive industries.

\section{INDEPENDENT VARIABLE: ENVIRONMENTAL INSTITUTIONAL DISTANCE.}

The Environmental Sustainability Index (ESI) in 2002, benchmarks the country's' ability to protect their natural environment, published by Yale Center for Environmental Law and Policy and Center for International Earth Science Information Network of Columbia University (Esty et al 2005; Aguilera-Caracuel et al., 2012). This index utilizes multiple datasets into 21 indicators and five categories of environmental sustainability. 
The environmental institutional distance between countries was calculated as difference in the absolute value between the global ESI value of the headquarters' and subsidiaries' countries. Regardless of whether a MNE has one or more subsidiaries or affiliates in a country, that country was considered only once for calculating environmental institutional distance. That means, if country A and country B has, say 1 and 10 subsidiaries respectively, both the countries will have the same weightage for calculation. Following Hair et al. (2008) the variable was normalized. ESI values close to zero would show that headquarters' and subsidiaries’ countries have similar institutional profile, whereas higher values show that differences between the institutional profiles of the countries are higher and therefore those countries protect their natural environment differently.

\section{CONTROL VARIABLES}

Alnajjar (2000) examined association between individual firm characteristics, namely, size, profitability and industry classification, and social responsibility disclosures and found that only size was related to disclosure. The Corporate Social Responsibility (CSR) ratings are affected by firms’ size (Johnson and Greening, 1999). Videras and Albini (2000) suggested that owing to their visibility to consumers and regulators, larger firms are more likely to join voluntary environmental programs. Bansal (2005) used firm size as a control for studying sustainability development in firms, stating that both resource utilization and institutional pressures are influenced through firm size. AragonCorrea (1998) in a study of firms in Spain found that firms' corrective approaches to natural environment were dependent on the firm size. Firm size is included as a control as 
larger firm size has greater influence on community, other stakeholders and was measured as log of total assets, where total assets is in million dollars.

Substantial investment is needed for implementing environmental programs by the firms (Christman and Taylor, 2001). The slack resources of a firm can be a motive for investing in the environmental programs by that firm. Therefore, we control for slack resources as the ratio of current assets over current liabilities (Bansal, 2005).

The financial performance of the firm can have implications for participating in the voluntary disclosure program as these firms have enough ability to sustain the costs associated with participation. Following Bansal (2005) and Aguilera-Caracuel et al. (2011) the return on equity of the MNE for the corresponding year was used as a proxy to control the financial performance. Return on Equity measures the net income obtained per shareholder equity and therefore is considered as a better reflection of financial performance for this study based on the MNEs participating in the voluntary CDP where investors are directly involved.

\section{STATISTICAL TECHNIQUE}

In order to test the hypotheses, the logistic regression model is used, as the dependent variables are dichotomous to examine predictive effect of orientation of MNEs on the carbon performance and also on the predictive effect of home country, European and US multinationals, on carbon performance. Logistic regression is appropriate in estimating a binary dependent variable using the maximum likelihood estimation procedure (Tansey et al., 1996). The statistical analysis for logit models are based on binomial distribution. 


\section{CHAPTER V \\ RESULTS}

The CDP report has evolved and gone through the financial crisis period; this dissertation considered data from recent three years (2011, 2012, 2013) of CDP reports for three reasons: First, the last three years of data from CDP reports will give a larger sample size. Second, it will give a realistic picture of business environment with respect to climate change. Third, after the recent financial crisis, drastically evolving climaterelated compliance requirements imply that the firms have to transform their resources into capabilities that help them achieve competitive advantage through the 'green/climate competencies’ alone (Rugman and Verbeke, 1998).

Hence, the sample selection was based on random sample of 108 firms each year (2011, 2012, 2013), which was part of the CDP report where carbon performance data was available. Therefore, the sample size for logistic regression analysis of the global and regional-orientation of multinationals on carbon performance has 324 firm-year observations.

Table 6: 2 x 2 matrix of MNE orientation and carbon performance

\begin{tabular}{|c|c|c|c|}
\hline & Globa & Region & Tota \\
\hline Orientation/Performance & l & al & l \\
\hline \multirow[t]{2}{*}{ High performers (A and A-) } & 93 & 36 & 129 \\
\hline & $(28.7)$ & $(11.1)$ & 8) \\
\hline \multirow[t]{2}{*}{ Low performers (B,C,D,E) } & 60 & 135 & 195 \\
\hline & (18.5) & (41.7) & 2) \\
\hline \multirow[t]{2}{*}{ Total firms } & 153 & 171 & 324 \\
\hline & $(47.2)$ & (52.8) & $.0)$ \\
\hline
\end{tabular}

Figure in parentheses represent the percentage with respect to total firms (324) for 2011-2013 
The sample used for logistical regression analysis for testing the hypotheses for the effect of orientation of MNEs on carbon performance, has a distribution of 153 firmyears under global orientation and 171 firm-years under regional-orientation which corresponds to $47.2 \%$ and $52.8 \%$ of the total sample size of 324 firm years. Under the high performers, 93 global-oriented firms and 36 regional-oriented firms were observed corresponding to $28.7 \%$ and $11.1 \%$ of the total sample. This distribution shows a definite dominance of MNEs with global-orientation in the high carbon performing group as compared to the regional-oriented MNEs. With regard to the low performing MNEs, regional-oriented firms dominate the global-oriented firms in this sample. So this $2 \mathrm{x} 2$ matrix tabulation reveals that global-oriented MNEs have an advantage over the regional oriented MNEs. Whether this apparent relationship is statistically significant or not will be tested using the logistical regression analysis.

Table 7 shows the distribution of the sample of 324 firm-years (108 firms and 3 years, i.e., 2011-2013) into different industry-sectors. There are total of 129 firm-years under high performers (A and A-) and there are 195 firm-years under low performers (B, C, D, and E). So, out of the total sample of 324 firm-years, high carbon performing firms consists of $40.4 \%$ while low carbon performers comprise a majority of $61.1 \%$. This is in alignment with the trend - higher number of firms under low performance and fewer numbers of firms under high performance in the CDP reports 2011-13.

Table 7: High and low performers - Industry wise distribution

\begin{tabular}{lrrr}
\hline & $\begin{array}{r}\text { High } \\
\text { Performers }\end{array}$ & $\begin{array}{r}\text { Low } \\
\text { Performers }\end{array}$ & Total \\
\hline Consumer Discretionary & 15 & 21 & 36 \\
& $(4.6)$ & $(6.5)$ & $(11.1)$ \\
Consumer Staples & 18 & 18 & 36
\end{tabular}


Financials

Healthcare

Industrials

Materials

Telecommunication

Services

Utilities

High performers include MNEs falling under performance categories of A or A- and Low performers fall under $\mathrm{B}$ or $\mathrm{C}$ or $\mathrm{D}$ or $\mathrm{E}$ categories in the CDP reports

Table 8 shows the distribution of US and European multinationals across the different performance categories. The figures in the parentheses indicates the percentage of US multinationals to combined number of US and European multinationals in the CDP survey reports from 2010 through 2013. The US and European multinationals in the CDP report maintains almost an equal proportion throughout all the years from 2010 through 2013. However, the distribution of US and European multinationals across different performance category varies. The US companies have been gradually increasing their presence in A performance category over the years as compared to European companies (exception in the year 2010). In the A- performance category, the US firms are leading 
the European firms as in the year 2013. In C performance category currently less number of US firms and in C D and E categories US firms dominate European firms.

The performance categories 'B', 'C', “ $D$ ', and ' $E$ ' shows that each of these categories have more or less same proportion of firms falling under the category in the year 2010 and 2013. For the performance category 'A-', there are two years with no firms falling under this category and comparing the other two years 2011 and 2013, there is an increase in the number of firms. There is increase in proportion and in absolute number for firms coming under the performance category 'A' over the years.

Table 8: Performance distribution of European and US multinationals

\begin{tabular}{llrrrrrrr}
\hline Year & \multicolumn{1}{c}{ Firm } & \multicolumn{1}{c}{ A } & \multicolumn{1}{c}{ A- } & \multicolumn{1}{c}{ B } & C & D & E & Total \\
\hline 2013 & European & 29 & 7 & 65 & 18 & 5 & 2 & 126 \\
& USA & 17 & 14 & 52 & 31 & 19 & 3 & 136 \\
& & $(36.96)$ & $(66.67)$ & $(44.44)$ & $(63.27)$ & $(79.17)$ & $(60.00)$ & $(51.91)$ \\
2012 & & & & & & & & \\
& European & 21 & 0 & 48 & 23 & 14 & 10 & 116 \\
& USA & 8 & 0 & 56 & 31 & 29 & 4 & 128 \\
& & $(27.59)$ & & $(53.85)$ & $(57.41)$ & $(67.44)$ & $(28.57)$ & $(52.46)$ \\
2011 & & & & & & & & \\
& European & 16 & 13 & 36 & 28 & 19 & 7 & 119 \\
& USA & 6 & 7 & 39 & 41 & 19 & 11 & 123 \\
& & $(27.27)$ & $(35.00)$ & $(52.00)$ & $(59.42)$ & $(50.00)$ & $(61.11)$ & $(50.83)$ \\
2010 & European & 27 & 0 & 65 & 26 & 1 & 0 & 119 \\
& USA & 11 & 0 & 57 & 48 & 6 & 0 & 122 \\
& & $(28.95)$ & & $(46.72)$ & $(64.86)$ & $(85.71)$ & & $(50.62)$ \\
\hline
\end{tabular}

The figure in parentheses indicates the proportion of US multinationals as a proportion to the combined number of US and European multinationals, under each performance category for each year

The final sample for analysis of the home country effect on carbon performance is given in the Table 9. The proportion of European (61.41\%) and U.S. MNEs (38.6\%). 
Table 9: Sample of European and US multinationals used for the analysis

\begin{tabular}{lrrr}
\hline & High Performers & Low Performers & Total \\
\hline European & 83 & 116 & 199 \\
& $(25.6)$ & $(35.8)$ & $(61.4)$ \\
U.S. & 46 & 79 & 125 \\
& $(14.2)$ & $(24.4)$ & $(38.6)$ \\
Total & 129 & 195 & 324 \\
& $(39.8)$ & $(60.2)$ & $(100.0)$ \\
\hline
\end{tabular}

\section{DESCRIPTIVE STATISTICS}

Out of the sample of 324 MNEs from the CDP Global reports 2011, 2012 and 2013. The sample consisted of $57 * 3=171$ firms with regional-orientation and $51 * 3=153$ firms with global-orientation. The dummy variable industry type, with the mean of 0.44 , indicates that there was not much difference in the distribution of firms in both the environmentally sensitive industries and non-environmentally sensitive industries (Table $10)$.

Table 10 shows the correlation between different variables for testing the relationship of MNE- and home country-orientations on MNEs' carbon performance. MNE orientation (global and regional) and the dependent variable carbon performance had significance level at $\mathrm{p}<0.05$. Similar degree of strength of correlation is noticed between European and US MNEs with carbon performance. This shows that MNE orientation and Home country of MNEs have significant association with carbon performance of the MNEs. There is also significant correlation $(\mathrm{p}<0.05)$ between MNE orientation and Environmental institutional distance. Firm size is also significantly correlated with firm-orientation. This indicates that the big MNEs are having statistically significant association with MNEs' orientation. 
Interestingly, environmental distance has a negative significant association with the industry type, where environmentally sensitive industries are coded as 1 and nonenvironmentally sensitive as 0 . The negative correlation implies high institutional distance associated with non-environmentally sensitive industries and lower institutional distance less associated with environmentally sensitive industries. This would also imply that MNEs in environmentally sensitive industries are probably internationalizing to countries with similar institutional profiles as their own country as compared to the MNEs in environmentally non-sensitive industries. All the significant associations are at $\mathrm{p}<0.05$.

Table 10: Descriptive statistics and correlation

\begin{tabular}{|c|c|c|c|c|c|c|c|c|c|c|c|}
\hline & & Mean & SD & 1 & 2 & 3 & 4 & 5 & 6 & 7 & 8 \\
\hline 1 & Carbon Performance & & & & & & & & & & \\
\hline 2 & Global/Regional Orientation & .47 & .50 & $.24 * *$ & & & & & & & \\
\hline 3 & European/US MNEs & .61 & .55 & $.19 * *$ & 0.15 & & & & & & \\
\hline 4 & Industry Type & .44 & .49 & .10 & $.18 * *$ & .17 & & & & & \\
\hline 5 & $\begin{array}{l}\text { Environmental Institutional } \\
\text { Distance }\end{array}$ & .04 & .51 & .12 & $.24 * *$ & .12 & $-0.18 * *$ & & & & \\
\hline 6 & $\begin{array}{l}\text { Financial Performance } \\
\text { (ROE) }\end{array}$ & .09 & .89 & .17 & .16 & .11 & -0.02 & .01 & & & \\
\hline 7 & $\begin{array}{l}\text { Firm Size (Log of Total } \\
\text { Assets) }\end{array}$ & 11.0 & $\begin{array}{l}1.5 \\
7\end{array}$ & .05 & $.26 * *$ & .10 & .10 & .11 & .15 & & \\
\hline 8 & Slack Resources & 1.7 & .99 & -0.15 & -0.01 & 0.08 & -0.12 & .02 & .12 & -.06 & \\
\hline
\end{tabular}

Logistic regression was run with the dependent variable as carbon performance. The results with odds ratio for the independent and control variables are given in Table 11. The model had a significant likelihood ratio of chi square at 11.29 to 11.87 with $\mathrm{p}$ $<0.05$. This implies that each one of the models as a whole fit significantly better than a model with no predictors. The results indicate that the ratio of foreign sales to total sales 
(FSTS), the proxy of MNE orientation, is significant with a $\mathrm{p}<0.05$. Therefore, the analysis shows that there is difference in the performance between the firms with globalorientation vs. regional-orientation as initially reflected in the high correlation of 0.24 at $\mathrm{p}<0.05$ (Table10). The odds-value of 5.22 for the FSTS in Table 11 implies that the odds for global-oriented MNEs to have better environmental performance than regionaloriented MNEs is 5.22. Therefore, hypothesis 1 is supported.

Models 2 to 5 indicate tests for hypotheses 2 to 4 . Home country of European Union increased the odds that MNEs would disclose carbon performance by a factor of $3.97(\mathrm{p}<0.05)$. The interaction between the MNE-orientation and industry type had an odds ratio of 2.1 but did not yield any statistical significance. That would mean the carbon performance of global- vs. regional-MNEs is not differently influenced by the industry type. However, there is main effect of industry type on carbon performance in all the models $(\mathrm{p}<0.1)$. Therefore hypothesis 3a is supported. The variable industry type is significant with odds ratio less than one, meaning that environmentally non-sensitive industries have better carbon performance, and this is true for both global- and regionalMNEs because of no interaction effect. This is an interesting revelation of this study where MNEs in environmentally non-sensitive industries had a better carbon performance as compared to those in the environmentally sensitive industries. Therefore, our hypothesis 3b is not supported.

The environmental institutional distance by itself has significant impact in the model at $\mathrm{p}<0.5$. Hypothesis $4 \mathrm{a}$ is supported. The odds ratio of around 0.30 for environmental institutional distance implies that MNEs with higher environmental institutional distance between home and host country of operation have odds of 0.30 to 
have better carbon performance as compared to MNEs with low environmental institutional distance between home and host country. In other words, when the institutional distance between the home country of MNE and its host country of operation is high, the MNE is likely to have poor carbon performance. The interaction of MNEorientation with the environmental institutional distance did not yield any statistical significance. This would imply that higher environmental institutional distance has a negative effect on the relationship with carbon performance of the MNE regardless of whether it is global-oriented or regional-oriented. In other words, the lower (closer) the environmental institutional distance between home country of MNE and host country of MNE affiliates, the higher the likelihood of carbon performance. Another important observation is that the control variable slack resource and financial performance measured as return on equity was significant $(\mathrm{p}<0.10)$. Therefore, hypothesis $4 \mathrm{~b}$ is supported and 4c is not supported.

When European and US MNEs are compared for their carbon performance, the odds ratio obtained was $3.97(\mathrm{p}<0.10)$. So the result validates that home country institutional effect exists for carbon performance in the context of European and US MNEs. Thus, hypothesis $2 \mathrm{a}$ is supported. These results support the observation in Table 8 that US MNEs are seen dominating in the low performing category and European MNEs slightly dominating over the US MNEs in the high performing category. 
Table 11: Logistic regression results

\begin{tabular}{|c|c|c|c|c|c|}
\hline & (1) & (2) & (3) & (4) & (5) \\
\hline $\begin{array}{l}\text { Control variables } \\
\text { Total Assets (log) }\end{array}$ & $\begin{array}{c}0.953 \\
(0.162)\end{array}$ & $\begin{array}{c}0.909 \\
(0.166)\end{array}$ & $\begin{array}{c}0.923 \\
(0.161)\end{array}$ & $\begin{array}{c}0.945 \\
(0.168)\end{array}$ & $\begin{array}{c}0.935 \\
(0.159)\end{array}$ \\
\hline Slack Resources & $\begin{array}{l}0.432 * \\
(0.210)\end{array}$ & $\begin{array}{l}0.428^{*} \\
(0.208)\end{array}$ & $\begin{array}{l}0.442^{*} \\
(0.206)\end{array}$ & $\begin{array}{l}0.451^{*} \\
(0.212)\end{array}$ & $\begin{array}{l}0.4446^{*} \\
(0.200)\end{array}$ \\
\hline $\begin{array}{l}\text { Financial Performance } \\
\text { (ROE) }\end{array}$ & $\begin{array}{c}0.184^{*} \\
(0.102)\end{array}$ & $\begin{array}{l}0.182^{*} \\
(0.100)\end{array}$ & $\begin{array}{c}0.178^{*} \\
(0.108)\end{array}$ & $\begin{array}{c}0.189 * \\
(0.104)\end{array}$ & $\begin{array}{l}0.176^{*} \\
(0.101)\end{array}$ \\
\hline \multicolumn{6}{|l|}{ Independent variables } \\
\hline $\begin{array}{l}\text { MNE orientation } \\
\text { (Foreign Sales to Total } \\
\text { Sales, FSTS) } \\
\text { (H1, predicted odds ratio } \\
>1 \text { ) }\end{array}$ & $\begin{array}{l}5.22 * * \\
(3.12)\end{array}$ & $\begin{array}{l}4.99 * * \\
(2.96)\end{array}$ & $\begin{array}{l}4.92 * * \\
(3.21)\end{array}$ & $\begin{array}{l}4.75^{* *} \\
(3.41)\end{array}$ & $\begin{array}{l}4.20^{* *} \\
(2.98)\end{array}$ \\
\hline $\begin{array}{l}\text { European US MNEs } \\
\text { (H2a,predicted odds ratio } \\
>1 \text { ) } \\
\text { (H2b,predicted odds ratio } \\
<1 \text { ) }\end{array}$ & & $\begin{array}{l}3.97^{*} \\
(2.79)\end{array}$ & & & $\begin{array}{l}4.09 * \\
(2.99)\end{array}$ \\
\hline $\begin{array}{l}\text { Industry Type } \\
\text { (H3a, predicted odds ratio } \\
\text { is significant } \\
\text { H3b, predicted odds ratio } \\
>1 \text { ) }\end{array}$ & $\begin{array}{l}0.391 * \\
(0.345)\end{array}$ & $\begin{array}{l}0.404^{*} \\
(0.399)\end{array}$ & $\begin{array}{l}0.354^{*} \\
(0.368)\end{array}$ & $\begin{array}{l}0.402 * \\
(0.401)\end{array}$ & $\begin{array}{l}0.337^{*} \\
(0.339)\end{array}$ \\
\hline $\begin{array}{l}\text { Environmental Institutional } \\
\text { Distance } \\
\text { H4b, predicted odds ratio } \\
<1 \text { ) }\end{array}$ & $\begin{array}{c}0.301^{* *} \\
(0.102)\end{array}$ & $\begin{array}{r}0.320^{* *} \\
(0.104)\end{array}$ & $\begin{array}{c}0.287^{* *} \\
(0.099)\end{array}$ & $\begin{array}{c}0.310^{* *} \\
(0.109)\end{array}$ & $\begin{array}{l}0.299 * * \\
(0.101)\end{array}$ \\
\hline $\begin{array}{l}\text { MNE orientation x Industry } \\
\text { Type } \\
\text { H4d, predicted odds ratio } \\
>1 \text { ) }\end{array}$ & & & $\begin{array}{c}2.10 \\
(2.97)\end{array}$ & & $\begin{array}{c}2.06 \\
(2.88)\end{array}$ \\
\hline $\begin{array}{l}\text { MNE orientation x } \\
\text { Environmental Institutional } \\
\text { Distance } \\
\text { H4c, predicted odds ratio } \\
>\text { 1) }\end{array}$ & & & & $\begin{array}{c}3.49 \\
(2.04)\end{array}$ & $\begin{array}{c}3.44 \\
(2.05)\end{array}$ \\
\hline Year effects & Yes & Yes & Yes & Yes & Yes \\
\hline Observations & 324 & 324 & 324 & 324 & 324 \\
\hline Pseudo R ${ }^{2}$ & 0.162 & 0.179 & 0.163 & 0.188 & 0.179 \\
\hline $\mathrm{Chi}^{2}$ & $\begin{array}{c}11.34 \\
0.031^{* *}\end{array}$ & $\begin{array}{c}11.37 \\
0.027 * *\end{array}$ & $\begin{array}{c}11.87 \\
0.026^{* *}\end{array}$ & $\begin{array}{c}11.29 \\
0.030 * *\end{array}$ & $\begin{array}{c}11.77 \\
0.027 * *\end{array}$ \\
\hline
\end{tabular}

Note: Models use logistic regression estimates (odd-ratios) with standard error parentheses. ${ }^{*} \mathrm{p}<0.10,{ }^{* *} \mathrm{p}<$ $0.05,{ }^{* * *} \mathrm{p}<0.01$. The dependent variable is carbon performance of the firm and is binary. All models include year effects. 


\section{CHAPTER VI DISCUSSION}

This dissertation argued that firm-capabilities, institutional pressures arising out of differences in institutional context, as well as industrial influence, are associated with an environmental concern of global dimension, carbon performance of multinational companies. The institutional pressure also includes the voluntary sustainability initiative (Wijen, 2014) which in this dissertation is the CDP report. Carbon performance was measured as the evidence of climate strategy adopted by firms, into their business processes and in value chains. The dissertation builds up the theoretical framework separately based on resource-based view, institutional approach, and industrial influences to elucidate the different facets and drivers of carbon performance (climate strategy) of MNEs. However, there will be combined influences of these three factors on each individual firm which are also taken into account by focusing on each one of these three factors individually to explore the possible dimensions and processes that determine the carbon performance of MNEs. Thus, this dissertation empirically addresses the unique environmental issues of climate change (Lundan, 2011) which is a distinctive strategically driven international business issue (Pinkse and Kolk, 2009).

One key argument of this dissertation is that there exists difference in carbon performance of MNEs based on their orientation: either global or regional. The classification of global- and regional-orientation of MNEs is based on the ratio of home regional sales to total sales of MNEs. If the ratio is less than or equal to 0.50 , the MNE is classified as global-oriented MNEs. If the ratio is greater than 0.50, those MNEs are classified as regional-oriented MNEs. The theoretical framework for this argument was 
based on the resource based view. The results confirmed that the MNEs with globalorientation have a better carbon performance than that of MNEs with regionalorientation. Since the climate change is a global concern (Ruggie, 2004), the globaloriented MNEs as carriers and distributors of value (Stiglitz, 2002) have global outreach, capacity and need for high carbon performance across borders. Consequently, firmspecific advantages and their transfer will be more valuable, easy and profitable for global-oriented MNEs compared with that of regional-oriented MNEs. The better carbon performance (climate performance) by global-oriented MNEs is relevant because the onesize fits all approach was not found to work in different institutional settings as observed in the disastrous performance by Monsanto in internationalizing its standard technology worldwide (Hull et al., 2014). Hence, global-oriented MNEs, even though they have better resources and capabilities to standardize the climate capabilities across different borders, effectively utilizing the capabilities successfully across the globe remains a challenge. The global-oriented MNEs are also under more pressure to consider differences in their climate strategy in different institutional settings across the world compared to regional-oriented MNEs. To broadly generalize the result, would imply a competitive advantage for global-oriented MNEs to base their competitive advantage on climate strategy. The main challenge is to make sure the 'water-bed effect', (Wijen, 2014) where the solution to carbon emission reduction creates another problem undermining the competitive advantage of the MNE --doesn't happen.

We found that the industry type impacts the carbon performance of the MNEs. However, contradicting the hypothesis that MNEs in environmentally sensitive industries will have better carbon performance, the results partly supported that MNEs in non- 
environmentally sensitive industries have a better carbon performance. This is an interesting result that contradicts what literature suggests. One of the reasons for this result could be that firms are participating in the CDP for publicity purposes and internally firms are skeptical of the true impact the program participation can provide for their environmental performance (Videras and Alberini, 2000). It could also be that firms are resorting to 'greenwashing' to avoid accusations from stakeholders (Delmas and Curuel Burbano, 2011) in order to avoid adverse reputation (Hoffman, 2005) or to avoid litigation risk mainly in the U.S. (Lash and Wellington, 2007). It is noted that the MNEs that are intensively dependent on carbon in their business processes cannot change their competitive strategy at once and their decision to participate in the voluntary environmental performance disclosure programs is because of their visibility to consumers (Pinkse and Busch, 2013). We have seen that MNEs from nonenvironmentally sensitive industries such as financials are participating in the CDP and represent a major group of firms having high carbon performance. Other factors such as reputational benefits for the firm, its visibility across various stakeholders, and its complementary assets may also determine how firms respond to institutional pressure, apart from their firm-specific environmental capabilities, even if they are from the same industry. So to project good image for carbon intensive industries, is different than it is for companies in the oil industry. Industries such as mining, steel, and cement, even though are also carbon intensive industries, are less scrutinized and therefore not required as much to project a good image for external stakeholders (Pinkse and Busch, 2013).

Another interesting result is that the institutional distance measured as environmental institutional distance had a significant effect $(p<0.05)$. The main effect of 
environmental institutional distance is, therefore, stronger than that of the industry type $(\mathrm{p}<0.10)$. Low environmental institutional distance between home and host country of MNE had a higher likelihood of higher performance for both global- and regionaloriented MNEs. In other words, there is no interaction effect of MNE orientation and environmental institutional distance associated with carbon performance of the MNE. This observation supports the finding of Aguilera-Caracuel et al. (2012) that low environmental institutional distance allows MNEs to gain legitimacy easily and also to transfer environmental standards easily within their network.

Supporting Makino et al.’s (2000) observation that country effects are important for firm performance, carbon performance was found to be superior for MNEs from the European Union compared to MNEs from U.S. This can be considered natural because the European Union has traditionally have been vociferously supporting the carbon reduction strategy adoption regardless of whether other developing countries adopt or not. This was not the position of the U.S. till recently. So the home country institutional effect as well as the global institutional context of politics has played a significant role in the emergence of carbon emission reduction policies by different governments. The debate of undermining profitability was a serious concern in the U.S., even though recently U.S. development did not stagnate but rather accelerated when strict air pollution was controlled by the Clean Air Act, 1963 and its subsequent modifications. Similarly, proponents argue, carbon friendly businesses can promote innovation and provide a competitive advantage to companies while providing a better, healthy world for the future generations. Some of the staunch opponents continue questioning the basis of the climate 
science but climate science is getting wider acceptance since the recent droughts, wildfires, and other climatic disasters and reported health issues related to climate issues.

Climate change is an environmental issue of global concern and sustainability is increasingly becoming a subject of interest for MNE strategy. Pressure from stakeholders, especially from global institutional investors, has made adopting and adapting to climate change strategy a more pertinent issue of immediate concern. The role of business in global environmental governance has become a reality in many areas and the role is increasingly sought by many supra national agencies (Ruggie, 2004; Levy, 2005; Ioannou and Serafeim, 2012). Voluntary disclosure programs as a first step can be considered to strengthen not only as a strategy for individual firms but also as industry partnership and governmental partnerships. This seems to be more relevant as the environmental protection agency (EPA) in June 2014 has come up with a proposal to substantially cut carbon emissions in the power sector of U.S. by the year 2030. If this is to be considered as a signal to the world, future innovation and strategies are likely to be carbon-friendly. Earlier, Swiss Re, the world’s largest reinsurer, had requested energyintensive firms to disclose whether they are meeting carbon reduction obligations under any accord such as the Kyoto Protocol. In the current situation, this requirement is likely to prevail widely across insurers and reinsurers. The concept of carbon insurance is increasingly considered to be relevant and similar to the category of fire insurance. Fire is rare to occur but an occurrence means huge loss. These developments are likely to lead to high insurance premiums and even to affect the coverage of the carbon polluting firms. Since the influence of 'investor-driven climate change governance networks' was found to have significant role and authority in global environmental politics (MacLeod 
and Park, 2011), this dissertation focused on the CDP where 722 institutional investors representing \$87 trillion in assets are co-signatories, along with the Carbon Disclosure Project (a non-governmental organization), in requesting carbon emission and strategy information from the Global 500 MNEs. Another aspect that is relevant is that firms are found to adhere to carbon norms either voluntarily or as a response to stakeholder pressure (Pinkse and Busch, 2003). It is relevant to note that Unilever, for example, has created a consumer goods forum where big manufacturers and retailers worth $\$ 3$ trillion in sales together have decided not to sell any products from activities such as illegal deforestation (Polman, 2014). This activity, of course, will have ramifications across the entire supply chain associated with these manufacturers and retailers.

How this mechanism would unfold and affect the fundamental strategies of the firm is yet to be clearly understood. This dissertation focuses on the relationship between MNEs and carbon performance and is important for several reasons. First, several recent major initiatives, especially by non-governmental organizations, exert pressure on firms to increase transparency through disclosures of climate change information. Second, our inquiry enhances knowledge on environmental sustainability and performance literature. The effect that global- or regional- orientation of multinationals have on their environmental performance is important because both financial and environmental performances are complementary to each other. Third, we consider firm effect, institutional effect, and industry effect as determinants of the carbon performance of the MNEs. We found that home country of MNEs is a determinant of its carbon performance even though not very significant. Regardless of home country effect or MNE orientation, institutional distance and industry type also determine the effect of carbon performance 
of MNEs. Fourth, both depth and breadth of internationalization are accounted for in this study by using both sales measure and institutional distance measure. Fifth, since climate change related strategy and performance is a recent development and still evolving, we explored the effect of industry type on the effectiveness of implementation.

Our major research objective was, however, to capture the effect of MNE orientation and home country effect on the commitment to 'sustainability', especially when climate change related strategy is considered as a 'megatrend' similar to what the business enterprises witnessed in the case of information technology and total quality management (Lubin and Esty, 2010). To this extent, this study contributes to the international business literature by showing that firms with global orientation and from home countries that institutionally support and promotes climate friendly strategies are likely to perform better in climate change related strategy that do not warrant local responsiveness.

The influence of corporations on global policy making was visible, for example, in the pressure they put during WTO agendas in pharmaceutical regarding intellectual property rights. However, the dropping of Multilateral Agreement on Investment in the 1990s due to a coalition of 600 organizations from 70 countries opposing it stating that MNEs will challenge domestic environmental and labor standards (Ruggie, 2004) is to be noted. Therefore, the managers of MNEs need to take into consideration the global climate change strategy not as another issue to 'project a good image' (Pinkse and Busch, 2013). This would mean that climate capabilities will be an important component of environmental capabilities of MNEs in their strategy to make the business profitable (Porter and Kramer, 2006). This would address the need and call by the United Nations, 
through its various agencies, for MNEs to play a greater role in social and environmentally responsible activities. Another implication for regional-oriented MNEs' managers is that once lower performance is cross-validated and confirmed there is a possibility that governments will come up with stricter regulations and/or scrutinize the regional-oriented MNEs more rigorously for their carbon performance. The scrutiny from regulators can be stricter if the environmental institutional distance between home and host country is high. It is obvious that a regional-oriented MNE with high institutional distance between its home and host county is more likely to come under the radar of the host country regulator. So, to that extent this can be considered as a wakeup call, especially for regional-oriented MNEs to consider their strategy. However, there is need for cross-validation in order to generalize this effect because, as Kolk and Perego (2013) noticed, previous studies have indicated high environmental performance of firms followed by both more and less voluntary disclosure by the firms.

\section{LIMITATIONS AND FUTURE RESEARCH}

The dissertation focused on a voluntary disclosure report, CDP to analyze the research questions. The data available showed certain peculiarities. First, some of the Global 500 companies contacted for the online survey did not to respond completely or responded only partially, either in one year or many years.

Second, some of the companies, over the years reported variation in their carbon performance. Since the carbon performance is measured as evidence of climate change 
strategy into the overall business strategy, the variation in performance is not expected in the consequent years.

Third, some drastic changes within the performance categories, mainly in the Aperformance category, were observed in the year 2012. There is continuous evolution of CDP process and companies gearing up to adjust to the voluntary disclosure mechanism suggested by recent discussions on climate change (Doha, 2012). On the positive side, the recent emphasis on climate change strategy promotion by the U.S. government may act as an important signal and incentive to businesses to improve their climate strategy and to adapt to environmentally friendly business practices and policies in a more effective manner. Given the fact that the European Union already has a good institutional environment promoting climate policy and strategy, and the U.S. has a majority of large global firms these developments would imply that the poor carbon performers are likely to be under increasing scrutiny in the near future. Obviously, investors are about to keenly observe firms’ environmental performance. Indeed, they already are monitoring environmental performance, and climate related emissions are accounted into their valuation as reflected in the stock prices of the companies; hence we can expect the CDP report in near future to encompass richer details of climate related strategy of firms.

Fourth is more of a measurement reason. The carbon disclosure by firms has 50 percent weight in calculating the carbon performance index. This could mean that high carbon emitters might disclose the details in order to improve legitimacy and reputation because those sectors have higher visibility in the society as well as to regulatory authorities. 
Fifth, the classification of industry type that we have adopted from the previous literature of Cho and Patten (2007) might have to be modified in the case of carbon emitters because this is a new and evolving phenomenon, unlike the traditional environmental performance issues such as toxic gas emission, water pollution, deforestation, and waste disposal. However, this suggestion is based only on a possibility, because it is noticed that non-environmentally sensitive firms are very actively participating in the voluntary disclosure process.

Sixth, the sample of 324 firm-years was selected based on the complete data available for the firms after omitting partial and missing values. However, given the fact that it is extremely difficult to get accurate data on climate change strategy of MNEs, the sample used is statistically sound and incorporated three years in order to accommodate the year-to-year fluctuations. To that extent, the analysis captures the variance to provide an exploratory understanding of what is happening in the corporate sector strategic orientation on climate change.

Seventh, the sample used is from a carbon disclosure report, a non-governmental organization where there is no legal commitment for the MNEs to disclose the data except that their disclosure may come under the scrutiny of the investors. However, since the focus of the study was comparison of strategy and investors by themselves are essentially the largest influential stakeholders of company strategy, this dissertation helps us to better understand the strategic orientation of companies related to climate change.

Eighth, while there are supporters proposing that business and social competency go hand in hand and/or are the one and the same, there are other views suggesting that drivers of competitive advantage need not necessarily drive social responsibility (Marcus 
and Anderson, 2006). The extent to which climate strategy is actually driven by firm's competitive advantage will be an interesting aspect to investigate.

Ninth, climate change related strategy is recent and rapidly evolving. The CDP requires firms to adopt Global Reporting Initiative’s (GRI) framework. The measures used by firms are not uniform even within an industry. The disclosure has different scopes such as reporting total emission and direct emissions, and firms tend to differ on their reporting. This could affect the performance measure because a minimum score of 50 in carbon disclosure is required for consideration with respect to categorization into the performance band.

Tenth, the finding of Rugman and Verbeke (2008) that MNEs in the service sector had a greater degree of home-region orientation than those in the manufacturing sector. The sample in this dissertation was predominantly comprised of non-service firms and this could be one reason that we found global-oriented MNEs had a significant difference over the regional-oriented MNEs. If the sample were predominantly service-oriented firms, the result could have been different. However, the observation that service sector firms in financials and information technology sectors were active in the high carbon performance category would weaken that argument. Such a study would require a more effective measurement mechanism and its standardization for each industry and comparison across the industries.

Finally, the climate performance score recognizes evidence of action taken by firms to integrate climate change strategy into their overall strategy, activities, and processes. Hence, while the carbon performance score give us the performance in terms 
of evidence of action, the score alone might not be sufficient to find out the real low carbon emitters at present and compare their real performance.

A combination of both qualitative and quantitative studies, focusing on firm, industry, and institutional factors, might be required to enhance our knowledge in this evolving research area which is gaining attention by academic scholars, practitioners, non-governmental organizations, and national governments. The methods can also be compared that with other existing measures of environmental performance to give us a better insight into the environmental capabilities and strategies of the firms with respect to climate change performance. The possibility of 'greenwashing', where the firms selectively disclose positive information about its environmental performance, is high for firms that are more likely to have positive environmental performance (Lyon and Maxwell, 2006). Pinkse and Busch’s (2013) argument that firms in high carbon salient industries will be scrutinized by various stakeholders, therefore are more likely to adopt 'greenwashing' is relevant. It would be an interesting future study to explore the high carbon performers as evidenced by their carbon disclosure for real carbon performance. To examine the carbon performance in the context of emerging market MNEs including Japanese MNEs and comparing MNEs from 'triad' would be another interesting research exercise.

\section{CONCLUSION AND IMPLICATIONS}

When the traditional notions of competitive advantage are becoming obsolete, innovativeness through environmental capabilities will usher competitive advantages for firms (Porter and van der Linde, 1995). The recent emphasis on climate change strategy 
by President Obama and the proposal by EPA in June, 2014 regarding reducing carbon emissions followed the argument of Porter (1990) in his book The Competitive Advantage of Nations. Porter observed that countries with strict environmental standards lead in exporting products affected by the very strict environmental regulations. Proponents of climate change policy in the U.S. argue that with the enactment of Clean Air Act, 1990 aimed at addressing ozone depletion, the competitiveness of US companies was not undermined. Carbon clean economy and competitiveness are complementary to each other benefitting a large variety of stakeholders in the present as well as future generations.

Berchicci et al. (2012) focused on a new type of capability. environmental capability, as a determinant of acquisition choice. Recent reports from international nongovernmental organizations such as Greenpeace (Greenpeace, April 2012) focus on dirty energy consumption caused by information technology giants such as Apple, Amazon, and Microsoft, while appreciating the steps taken for clean energy by Google, Yahoo, and Facebook in the new arena of 'cloud' data centers. According to this report, if the cloud had been a country, it would have had the fifth largest electricity demand in the world. Social movements are increasingly shaping government policies (Reid and Toffel, 2009) regarding environmental obligations for the firms. Developing countries are also matching the developed world in this external stakeholder pressure for conformance to environmental safety. Recently, investors have focused their attention on the 'sustainability' dimension and capabilities of companies in their assessment.

This dissertation investigated the likelihood of global-oriented multinationals to have better competitive capabilities with respect to regional-oriented multinationals in 
pursuing environmental capabilities, especially in relation to an environmental issue affecting countries across the globe. Further, home country effect on the climate strategy of MNEs was explored through comparing MNEs from European Union and U.S. Both the variables industry type and institutional distance were studied as main and interaction effects. The result showed superior carbon performance for global-oriented MNEs compared with regional-oriented MNEs. Home country institutions have a role in predicting the carbon performance of MNEs, as evidenced from the superior performance of European MNEs. Another interesting finding was MNEs in non-environmentally sensitive industries were likely to have better carbon performance which was against the hypothesized relationship. Lower institutional distance between the MNE and its operating locations increased the probability of having better carbon performance. We found that firms with global-orientation, as measured by the depth of internationalization, have better environmental performance with regard to a global environmental issue, i.e. carbon performance. These findings have direct implications for the investors given the fact that a group of 722 institutional investors with a combined $\$ 87$ trillion assets are part of the carbon disclosure project and the recent respondents include 81\% of Global 500 companies. These findings also have implications for both managers and public policy makers. Since the top managers are the decision makers, this study informs managers that firms with a higher proportion of foreign sales have a responsibility to better their environmental performance on global environmental issues.

In this dissertation, we also measured the breadth of internationalization by bringing in the environmental institutional distance between home country and host country of MNE affiliates. Therefore, our results also indicate that having a higher 
proportion of foreign sales over and above the regional sales influences managers to consider environmental regulation and concerns of different countries. Similarly, more than the number of subsidiaries, top managers at the headquarters may have to consider the similarity of institutional profile between the home and host country to standardize their environmental policies and strategies. Firms may find it easier to have a standardized strategy on an issue of global concern such as climate change, because that could be an easier option to execute and also enable the company to avoid the criticism that they are having double standards in environmental strategy in different countries. At the same time, firms with regional-orientation may not necessarily be concerned much about the allegation of double standards because they are geographically closer to the host countries and more likely to be closer institutionally and culturally. Public policy makers can use the results of this study while monitoring the implementation of environmental performance of the MNEs operating in their countries. The national governments may need to persuade MNEs with regional orientation ceteris paribus to improve the environmental performance as far as climate change performance is concerned. Comparing the institutional distance of the MNE network and home country of MNEs can also inform the national government about the environmental capabilities and legacy that a particular MNE is likely to have. Then the government can negotiate or interfere, if required. Another important aspect for consideration is that since integrating climate change strategy into the firm's core strategy will lead to green firm specific advantages, this could have implications for new products that global-oriented firms might develop. Organic, sustainable products and processes might have important implications, especially in industries such as agriculture, food processing, and restaurants. 
This strategy can have multiple advantages to the firm such as reputational benefits, higher profitability by targeting a niche market, universal appeal across space and time, and aligning their environmental capabilities environmentally, thereby building customer loyalty and thus providing competitive advantage from their competitors. Social and environmental commitment, then, doesn't have to be enforced through coercion, regulation, or incentives, nor there is any requirement on the part of firms to adopt cosmetic socially responsible activities that are greenwashing. The environmental capabilities and strategy of the firm will naturally be sustainable and environmentally friendly.

In conclusion, this study investigates how the regional- and global-orientation of the MNE and its home country's institutional effect affects environmental performance by taking a look at a critical global environmental issue - carbon performance. The study found that global-oriented firms have better environmental performance than regionaloriented companies. Given the definition of our measure of carbon performance, the implication is that global-oriented firms have environmental capabilities better integrated into strategy than regional-oriented firms. This study also reported that industry effect and institutional distance affects the carbon performance of the MNEs. The home country of the MNE, through its institutions, shapes the strategic choice and environmental capabilities of MNEs. 


\section{REFERENCES}

Acemoglu,D., Johnson,S., \& Robinson, J.A. 2001 - The colonial origins of comparative development: An empirical investigation. The American Economic Review. 91(5):13691401.

Aguilera, R. V., \& Jackson, G. 2003. The cross-national diversity of corporate governance: Dimensions and determinants. Academy of Management Review. 28(3): 447465.

Aguilera-Caracuel, J., Aragon-Correa, J. A., Hurtado-Torres, N. E., \& Rugman, A. 2012. The effects of institutional distance and headquarters' financial performance on the generation of environmental standards in multinational companies. Journal of Business Ethics. 105: 461-474.

Aguilera-Caracuel, J., Aragon-Correa, J. A., \& Hurtado-Torres, N. E. 2011. Extending the literature on the environmental strategy of MNEs. The Multinational Business Review. 19(4):299-310.

Aguinis, H., \& Glavas, A. 2012. What we know and don't know about Corporate Social Responsibility: A review and research agenda. Journal of Management. 38(4):932-968.

Alnajjar, F. K. 2000. Determinants of social responsibility disclosures of U.S. Fortune 500 firms: An application of content analysis. Advances in Environmental Accounting \& Management. 1: 163-200.

Al-Tuwaijri, S. A., Christensen, T. E., \& Hughes, K. E., II. 2004. The relation among environmental disclosure, environmental performance, and economic performance: a simultaneous equations approach. Accounting, Organizations and Society. 29: 447-471.

Ambec, S., \& Lanoie, P. 2008. Does it pay to be green? A systematic overview. Academy of Management Perspectives.22(4), 45-62.

Amit, R., \& Schoemaker, P.J. 1993. Strategic Assets and Organizational Rent. Strategic Management Journal. 14: 33-46.

Andonova L, Betsill,.M. M., Bulkeley H. 2009, “Transnational climate change governance” Global Environmental Politics. 9 52-73

Arago'n-Correa, J. A. 1998. Strategic proactivity and firm approach to the natural environment. Academy of Management Journal. 41(5): 556-567.

Aragon-Correa, J.A., and Sharma, S. 2003. A contingent resource-based view of proactive corporate environmental strategy. Academy of Management Review. 28(1):7188. 
Arora, S., \& Cason, T.N. 1996. Why do firms volunteer to exceed environmental regulations? Understanding participation in EPA's 33/50 program. Land Economics. 72(4):413-432.

Banalieva, E. R., \& Sarathy, R. 2010. The Impact of Regional Trade Agreements on the Global Orientation of Emerging Market Multinationals. Management International Review. 50: 797-826

Bansal P, \& Gao J. 2008. Dual mechanisms of business sustainability: unique effects and simultaneous effects. Paper presented at the annual meeting of the Academy of Management, Anaheim, CA.

Bansal, P. 2002. The corporate challenges of sustainable development. Academy of Management Executive. 16(2):122-131

Bansal, P. 2002. The corporate challenges of sustainable development. Academy of Management Executive. 16(2):122-131

Bansal, P. 2005. Evolving sustainability: a longitudinal study of corporate sustainable development. Strategic Management Journal. 26(3): 197-218.

Barney, J.B. 1991. Firm resources and sustained competitive advantage. Journal of Management. 17(1): 99-120

Baron, D.P., \& Diermeier, D. 2007. Strategic activism and non-market strategy. Journal of Economics \& Management Strategy. 16(3):599-634.

Bartlett, C, \& Ghoshal, S. 1989. Managing across borders: The transnational solution. Boston, MA: Harvard Business School Press.

Bartlett, C. A. 1986 Building and managing the transnational: The new organizational challenge. In M. E. Porter (Ed.), Competition in global industries. Boston: Harvard Business School Press.

Bartlett, C., Ghoshal, S., \& Beamish, P. 2008. The future of Transnational Enterprise: An evolving global role. Transnational Management. 5th edition. The McGraw-Hill companies. pp 662-667

Bartlett, C.A.,. \& Ghoshal, S. 1989. Managing across borders: The transnational solution. Boston, MA: Harvard Business School Press Bell Journal of Economics, 12:380-391.

Berchicci, L., Dowell, G., \& King, A. A. 2012. Environmental Capabilities and Corporate Strategy: Exploring Acquisitions Among U.S. Manufacturing Firms. Strategic Management Journal. 33(9):1053-1071. 
Berrone, P., and Gomez-Meija, L.R. 2009. Environmental performance and executive compensation: An integrated agency-institutional perspective. Academy of Management Journal. 52(1):103-126.

Berry, H., Guillén, M. F., \& Zhou, Z. 2010. An institutional approach to cross-national distance. Journal of International Business Studies. 41(9): 1460-1480.

Birkinshaw, J. M., Morrison, A.J. \& Hulland, J. 1995. 'Structural and competitive determinants of a global integration strategy'. Strategic Management Journal. 16: 637655.

Birkinshaw, J., Hood, N., \& Jonsson, S. 1998. Building firm-specific advantages in multinational corporations: The role of subsidiary initiative. Strategic Management Journal. 19: 221-241

Bloomberg. 2014. Obama says climate change growing threat to health. May 31. http://www.bloomberg.com/news/2014-05-31/obama-says-climate-change-growingthreat-to-health.html

Boiral, O. 2012. ISO certificates as organizational degrees? Beyond the rational myths of the certification process. Organization Studies. 33: 633-654.

Braun, M. 2014. EU Climate Norms in East-Central Europe. Journal of Common Market Studies. 52(3):445-460.

Busenitz, L. W., Gomez, C., \& Spencer, J. W. 2000. Country institutional profiles: Unlocking entrepreneurial phenomena. Academy of Management Journal, 43, 994-1103.

Campbell, D. 2004. A longitudinal and cross-sectional analysis of environmental disclosure in UK companies--a research note. The British Accounting Review,36.(1):107117.

Campbell, J. 2007. Why would corporations behave in socially responsible ways? An institutional theory of corporate social responsibility. Academy of Management Review. 32: 946-967.

Cantwell, J., Dunning, J. H., \& Lundan, S. M. 2010. An evolutionary approach to understanding international business activity: The co-evolution of MNEs and the institutional environment. Journal of International Business Studies. 41: 567-586.

Castanias, R., \& Helfat, C. 1991. Managerial resources and rents. Journal of Management. 17(1): 155-172.

CDP Global Report (2011), Carbon Disclosure Project 2011, London. 
Chadee, D. D., \& Matsson, J. M. 1998. Do service and merchandise exporters behave and perform differently?: A New Zealand investigation. European Journal of Marketing. 32(9/10):830-842.

Chandler, A. D. 1990. Scale and scope: The dynamics of industrial capitalism.

Cambridge, MA: Harvard University Press. Cohen, W., \& Klepper, S. 1996. Firm size and the nature of innovation within industries: The case of process and product R\&D. Review of Economics and Statistics, 78(2): 232-244.

Chandler, A. D., Jr. 1962. Strategy and structure: Chapters in the history of the American industrial enterprise. Cambridge, MA: MIT Press.

Chatterji A. K., Toffel M. W. 2010. How firms respond to being rated. Strategic Management Journal. 31: 917-945.

Chen, Y. 2008. The driver of green innovation and green image: Green core competence. Journal of Business Ethics. 81(3): 531-543.

Cho, C. H. \& Patten, D. M. 2007. The role of environmental disclosures as tools of legitimacy: A research note. Accounting, Organizations and Society.32:639-647.

Christensen, C.R., Andrews, K.R., Bower, J.L., Hamermesh, R.G. and Porter, M.E. 1987. Business Policy: Text and Cases, Irwin, Homewood, Illinois.

Christmann, P. 2004. Multinational companies and the natural environment:

Determinants of global environmental policy standardization. Academy of Management Journal. 47(5): 747-760.

Christmann, P. and Taylor, G. 2001. "Globalization and the environment: determinants of firm self-regulation in China”, Journal of International Business Studies.32(3): 439-458.

Clarkson P. M., Li, Y, Richardson G. D, Vasvari, F. P. 2008. Revisiting the relation between environmental performance and environmental disclosure: an empirical analysis. Accounting, Organizations and Society 33(4/5): 303-327.

Cleetus, R., Clemmer, S., \& Friedman, D. 2009. Climate 2030. A National Blueprint for a clean energy economy. Union of Concerned Scientists. www.ucsusa.org:1-179.

Collis, D. J., \& Montgomery, C. A. 1995. Competing on Resources. Harvard Business Review. Republished on July-August 2008. 140-150.

Cordano, M., Marshall, R. S., \& Silverman, M. 2010. How do small and medium enterprises go "green"? A study of environmental management programs in the U.S. wine industry. Journal of Business Ethics. 92: 463-478.

Corporations: A Critique and New Directions. The Academy of Management Review. 33(4): 994. 
Cuervo-Cazurra, A., \& Genc, Mehmet. 2008. Transforming disadvantages into advantages: developing country MNEs in the least developed countries. Journal of International Business Studies. 39: 957-979.

Del Rio, P. 2009. The empirical analysis of the determination for environmental technological change: A research agenda. Ecological Economics. 68(3): 861-878.

Delios, A. 2010. How can organizations be competitive but dare to care?. The Academy of Management Perspectives. 24(3): 25-36.

Delios, A., \& Henisz, W. J. 2003. Political Hazards, Experience, and sequential entry strategies: the international expansion of Japanese firms, 1980-1998. Strategic Management Journal. 24: 1153-1164.

Delmas MA, Toffel MW. 2008. Organizational responses to environmental demands: opening the black box. Strategic Management Journal. 29(10): 1027-1055.

Delmas, M. A., \& Curuel Burbano, V. 2011. The drivers of greenwashing. California Management Review. 54(1): 64-87.

Delmas, M., \& Montes-Sancho, M. 2010. Voluntary agreements to improve environmental quality: Symbolic and substantive cooperation. Strategic Management Journal. 31: 576-601.

Delmas, M.A. 2002. The diffusion of environmental standards in Europe and in the U.S. Policy Sciences. 35(1):91-119.

Dierickx, I., Cool, K., \& Barney, J. B.1989. Asset Stock Accumulation and Sustainability of Competitive Advantage. Management Science .35: 1504-1511.

DiMaggio, P., \& Powell, W. 1983. The iron cage revisited: Institutional isomorphism and collective rationality in organizational fields. American Sociological Review, 48: 147160.

Dowell, G., Hart, S., and Yeung Do, B. 2000. Do corporate global environmental standards create or destroy market value? Management Science. 46(8):1059-1074.

Dunning, J. H., \& Lundan, S. M. 2008. Multinational enterprises and the global economy. 2nd edn. Cheltenham: Edward Elgar.

Elango B, Sethi SP. 2007. An exploration of the relationship between country of origin and the internationalization-performance paradigm. Management International Review. 47: 369-392.

Elkington, J., 2004. Enter the triple bottom line. In: Henriques, A., Richardson, J. (Eds.), The Triple Bottom Line: Does It All Add up? Earthscan, London, pp. 1-16. 
Enkvist, P.A, Naucler, T., \& Oppenheim, J.M. 2008. Business strategies for climate change. McKinsey Quarterly. 24-33.

Espeland, W. N., \& Sauder, M. 2007. "'Rankings and Reactivity: How Public Measures Recreate Social Worlds.” American Journal of Sociology. 113:1-40.

Esty, D., Levy, M., Srebotnjak, T., \& Sherbinin, A. (2005). Environmental sustainability index: Benchmarking national environmental stewardship. New Haven: Yale Center for Environmental Law \& Policy.

Esty, D.C., \& Charnovitz, S. 2012. Green Rules to Drive Innovation. Harvard Business Review. 121-123

Fremeth, A. R., \& Shaver, J.M. 2013. Strategic rationale for responding to extrajurisdictional regulation: Evidence from firm adoption of renewable power in the US. Strategic Management Journal. 35:629-651.

Financial Times, April 27, 2012. http://www.ft.com/intl/cms/s/0/10b30e4c-88bc-11e1a526-00144feab49a.html\#axzz36HQs8fE7

Galan, J. I., González-Benito, J., \& Zuñiga-Vincente, J. A. 2007. Factors determining the location decisions of Spanish MNEs: An analysis based on the investment development path. Journal of International Business Studies, 38(6): 975-997.

Ghemawat, P. 2001. Distance Still Matters-The Hard Reality of Global Expansion. Harvard Business Review, 137-146.

Goldman Sachs Report. 2009. Change is coming: A framework for climate change. http://www.goldmansachs.com/our-thinking/gs-sustain/gs-sustain/climate-changeresearch-pdf.pdf

Grant, R.M. (1991). 'The Resource-Based Strategy Theory of Competitive Advantage: Implications for Strategy Formulation’. California Management Review, 33(3): 114-135.

Greenbiz.com, April 2012. (http://www.greenbiz.com/blog/2012/04/17/industrialsenergy-management)

Greenpeace, April 2012. How clean is your cloud.

http://www.greenpeace.org/india/Global/india/report/HowCleanisYourCloud.pdf

Griffin, P. A., Lont, D. H., \& Sun, Y. 2011. The relevance to investors of greenhouse gas emission disclosures. The University of New South Wales. School of Accounting Seminar.

Guler, I., Guillen, M. F., \& MacPherson, J. M. 2002. Global competition, institutions and the diffusion of organizational practices: The international spread of ISO 9000 quality certificates. Administrative Science Quarterly. 47: 207-233. 
Hair, J. F., Andersson, R. E., Tatham, R. L., \& Black, W. C. (2008).Multivariate analysis. New York: Prentice Hall.

Hall, J., Bachor, V., \& Matos, S. 2014. Developing and Diffusing New Technologies: Strategies for Legitimization. California Management Review. 56(3): 98-117

Hart, S.L. 1995. A natural-resource-based view of the firm. Academy of Management Review. 20(4):986-1014

Henisz, W. J., \& Zelner, B. A. 2001. The institutional environment for telecommunications investment. Journal of Economics \& Management Strategy. 10:123148.

Henisz, W. J. 2000 "The Institutional Environment for Economic Growth", Economics \& Politics. 12(1): 1-31.

Hoffman AJ. 1999. Institutional evolution and change: environmentalism and the U.S. chemical industry. Academy of Management Journal 42(4): 351-371.

Hoffman, A.J. 2005. Climate change strategy: The business logic behind voluntary greenhouse gas reductions. Ross School of Business. Working Paper No. 905.

Hull, C.E., and Rothenberg. 2008. Firm performance: The interactions of corporate social performance with innovation and industry differentiation. Strategic Management Journal. 29(7):781-789.

Hunt, C. B., \& Auster, E. R. 1990. Proactive environmental management: Avoiding the toxic trap. Sloan Management Review. 31(2): 7-18.

Hunt, C.B. \& Auster, E. R. 1990. Proactive Environmental Management: Avoiding the toxic trap. Sloan Management Review. 31: 7-18.

Hunter T, Bansal P. 2007. How standard is standardized MNC global environmental communication? Journal of Business Ethics. 71(2): 135-147.

Husted, W.B., and Allen, D.B. 2000. Is it to use ethics as a strategy. Journal of Business Ethics. 27(1/2):21-31.

Husted, W.B., and Allen, D.B. 2006. Corporate social responsibility in the multinational enterprise: strategic and institutional approaches. Journal of International Business Studies. 37: 838-849.

Ingram, P., \& Silverman, B. 2002. Introduction. In P. Ingram and B. Silverman (Eds), The new institutionalism in strategic management: 1-30. Amsterdam: Elsevier.

Ioannis, I., \& Serafeim, G. 2012. What drives corporate social performance? The role of nation-level institutions. Journal of International Business Studies. 43(9):834-864. 
Johnson, R.A. \& Greening, D.W. 1999. The effects of corporate governance and institutional ownership types on corporate social performance. Academy of Management Journal. 42(5): 564-576.

Jones, C., \& Levy, D. 2007. North American business strategies towards climate change. European Management Journal. 25(6):428-440.

Karkkainen, B. C., Fung, A., \& Sabel, C. F. 2000. After backyard environmentalism Toward a performance-based environmental regulation. American Behavioral Scientist. 44(4): 692-711.

Kennelly, J. J. 2000. Institutional Ownership and Multinational Firms: Relationships to Social and Environmental Performance. Garland Publishing Inc. pp1-120.

Khanna, T., \& Rivkin,J.W. 2001. Estimating the Performance Effects of Business Groups in Emerging Market. Strategic Management Journal. 22(1): 45-74.

King, A., \& Lenox, M. 2002. Exploring the locus of profitable pollution reduction. Management Science. 48(2):289-299.

King, A.A. \& Shaver, J.M. 2001. Are Aliens Green? Assessing foreign establishments' environmental conduct in the U.S. Strategic Management Journal. 22:1069-1085.

Knudsen, J. S. 2001a. Company delistings from the UN global compact: Limited business demand or domestic governance failure?. Journal of Business Ethics. 103: 331-349.

Knudsen, J. S. 2011b. "Which Companies Benefit Most from UN Global Compact Membership?" European Business Review Retrieved 15 Mar 2012, from http://www.europeanbusinessreview.com/?p=5280.

Kogut B, Zander U. 2003.A memoir and reflection: knowledge and an evolutionary theory of the multinational firm 10 years later. Journal of International Business Studies. 34: 505-515.

Kolk A. 2010. Mainstreaming sustainable coffee. Sustainable Development, doi: 10.1002/sd.507

Kolk, A., \& Mulder, G. 2011. Regulatory uncertainty and opportunity seeking: The case of clean development. California Management Review. 54(1):88-106.

Kolk, A. and Pinkse, J. 2008. A perspective on multinational enterprises and climate change: Learning from 'An inconvenient Truth'? Journal of International Business Studies. 39(8): 1359-1378. 
Kolk, A., \& van Tulder, R. 2005. Setting new global rules? TNC's and codes of conduct. Transnational corporations. 14(3):1-27.

Kostova, T., \& Roth, K. 2002. Adoption of an organizational practice by subsidiaries of multinational corporations: institutional and relational effects. Academy of Management Journal. 45(1): 215-233

Kostova, T., Roth, K., \& Dacin, M. T. 2008. Institutional theory in the study of multinational corporations: A critique and new directions. Academy of Management Review. 33(4): 994-1006.

Kostova, T., \& Zaheer, S. 1999. Organizational legitimacy under conditions of complexity: The case of multinational enterprise. Academy of Management Review. 24(1): 64-81.

KPMG International Survey of Corporate Responsibility Reporting 2011.

Lash J, \& Wellington F. 2007. Competitive advantage on a warming planet. Harvard Business Review 85(3): 94-103.

Laszlo, C., Sherman, D., Whalen, J. \& Ellison, J. 2005. How stakeholder value contributes to competitive advantage. Journal of Corporate Citizenship. 20:65-76.

Lenox M. J.,\& Eesley C,E. 2009. Private environmental activism and the selection and response of firm targets. Journal of Economics and Management Strategy. 18(1): 45-73

Levy, D.L. 2005. Business and the evolution of the climate regime. In The Business of Global Environmental Governance, (eds) P.J. Newell and D.L. Levy. MIT Press, Cambridge, Mass.

Lewis, B. W., Walls, J.L., \& Dowell, G.W.S. 2014. Difference in degrees: CEO characteristics and firm environmental disclosure. Strategic Management Journal. 35(5):712-722.

Lopez, L., Kundu, S., \& Ciravegna, L. 2009. Born global or born regional? Evidence from an exploratory study in the Costa Rican software industry. Journal of International Business Studies. 40: 1228-1238

Lubin, D. A \& Esty, D. C. 2010. The sustainability imperative. Harvard Business Review.

Lundan, S. 2011. Review of the book 'International business and climate change' by Jonatan Pinkse and Ans Kolk. Journal of International Business Studies. 42: 975-977

Lundqvist, L. 1974. The hare and the tortoise: Clean Air policies in the US and Sweden. Ann Arbor: University of Michigan Press. 
Luo, Y. \& Tung, R. L. 2007. International expansion of emerging market enterprises: A springboard perspective. Journal of International Business Studies. 38: 481-498.

Lyon TP., \& Maxwell, J.W. 2006. Greenwash: corporate environmental disclosure under threat of audit. Working paper, Stephen M. Ross School of Business, University of Michigan, Ann Arbor, MI.

Lyon, T. P., \& Shimshack, J. P. 2012. Environmental disclosure: Evidence from Newsweek’s green companies ratings. Business Society. 20(10): 1-44.

Lyon, T.P., \& Maxwell, J. W. 2003. Self-regulation and public voluntary environmental agreements. Journal of Public Economics. 87: 1453-1486.

MacLeod, M., \& Park, J. 2011. Financial Activism and Global Climate Change: The Rise of Investor-Driven Governance Networks. 11(2): 54-74.

Maignan, I., \& Ralston, D.A. 2002. Corporate social responsibility in Europe and the U.S.: Insights from businesses' self-presentations. Journal of International Business Studies. 33 (3): 497-514.

Manev, I.M., \& Stevenson, W. B. 2001. Nationality, cultural distance, and expatriate status: Effects on the managerial network in a multinational enterprise. Journal of International Business Studies. 32(2): 285-303.

Marcus, A.A. and Anderson, M.H. 2006. A general dynamic capability: Does it propagate business and social competencies in the retail food industry? Journal of Management Studies. 44(1):170-179.

Martin X, Salomon R. 2003. Knowledge transfer capacity and its implications for the theory of the multinational corporation. Journal of International Business Studies 34: 356-373.

Mercer. 2011. Climate change scenarios: Implications for strategic asset allocation. Mercer LLC, Carbon Trust, International Finance Corporation.

Murtha, T. P., \& S. A. 1994. Country capabilities and the strategic state: How national political institutions affect multinational Corporations’ Strategies. 15(S2):113-129.

Murtha, T. P., \& Lenway, S. A. 2007. Country capabilities and the strategic state: How national political institutions affect multinational corporation's strategies. Strategic Management Journal. 15(S2): 113-129.

North, D. C. 1990. Institutions, institutional change and economic performance. Cambridge, England: Cambridge University Press.

Patten, D. M. 2002. The relation between environmental performance and environmental disclosure: a research note. Accounting, Organizations and Society. 27: 763-777. 
Peng, M. W., Wang, D. Y. L., \& Jiang, Y. 2008. An institution-based view of international business strategy: A focus on emerging economies. Journal of International Business Studies, 39(5): 920-936.

Perez-Batres, L, A., Miller, V. V., Pisani, M. J., Henriques, I., \& Renau-Sepulveda, J.A. 2012. Why do firms engage in national sustainability programs and transparency sustainability reporting. Management International Review. 52: 107-136.

Peteraf, M. A. 1993. The Cornerstones of Competitive Advantage: A Resource-Based View. Strategic Management Journal. 14: 179-191.

Phene, A., \& Almeida, P. 2008. Innovation in multinational subsidiaries: the role of knowledge assimilation and subsidiary capabilities. Journal of International Business Studies. 39:901-919.

Pinkse, J., \& Busch, T. 2013. The emergence of corporate carbon norms: Strategic directions and managerial implications. Thunderbird International Business Review. 55(6): 633-645.

Pinkse, J., \& Kolk, A. 2009. International Business and Global Climate change. Routledge and EABIS. p 1- 200.

Pinkse, J., \& Kolk, A. 2012. Multinational enterprises and climate change: Exploring institutional failures and embeddedness. Journal of International Business Studies. 43: 332-341.

Polman, P. 2014. Business, Society and Future of Capitalism. . McKinsey Quarterly May, 2014.

Porter M. E. 1990. The Competitive Advantage of Nations. Free Press: New York.

Porter, M. E. 1996. America's Green Strategy. Business and the Environment - A Reader. Eds. Welford, R. and Starkley, R. Taylor \& Francis. 33-35.

Porter, M. E. \& Kramer, M. R. 2006. The link between competitive advantage and corporate social responsibility. Harvard Business Review. December 2006. 78: 1-13.

Porter, M.E., \& Kramer, M. R. 2011. The big idea: Creating shared value. Harvard Business Review. 89(1/2): 62-77.

Porter, M.E. and van der Linde, C. 1995. "Green and competitive: ending the stalemate", Harvard Business Review, Vol. 73 No. 5, pp. 120-34.

Powers, N., Blackman A., Lyon, T.P and Narain, U. 2011. Does disclosure reduce pollution? Evidence from India's green rating project. Environmental Resource Economics. Resources for the future paper research series. Paper No. 08-38. 
Prahalad, C.K., Hamel, G. 1990. 'The Core Competence of the Corporation'. Harvard Business Review, May-June pp79-91.

Prahalad, C.K.2005. The Fortune at the Bottom of Pyramid (Book)

Purvis, M., \& Grainger, A. 2004. Eds Sterling VA: Earthscan Publications Limited. Pp 401.

Qian, G., Li, L., Li, Ji., \& Qian, Z. 2008. Regional diversification and firm performance. Journal of International Business Studies. 39: 197-214.

Ramachandran, J., \& Pant. A. The liabilities of origin: An emerging economy perspective on the costs of doing business abroad. Advances in International Management. 23:231265.

Reid EM, Toffel MW. 2009. Responding to public and private politics: corporate disclosure of climate change strategies. Strategic Management Journal 30(11): 11571178.

Ricart, J. E., Enright, M. J., Ghemawat, P., Hart, S. L., \& Khanna, T. 2004. New Frontiers in International Strategy. Journal of International Business Studies. 35(3): 175200.

Roe, M. J. 2003. Political determinants of corporate governance: political context, corporate impact. New York: Oxford University Press.

Roome, N. 1992. Developing environmental management systems. Business Strategy and the Environment. 1: 11-24.

Roth, K., \& Morrison, A. J. 1992. Implementing global strategy: characteristics of global subsidiary mandates. Journal of International Business Studies. 23(4): 715-735.

Rowlands, I.H. 2001. The Kyoto Protocol’s ‘Clean Development Mechanism’: A sustainability assessment. Third World Quarterly. 22(5): 795-811.

Ruggie, J. G. 2004. Reconstituting the Global Public Domain - Issues, Actors, and Practices. European Journal of International Relations. 10(4): 499-531.

Rugman, A. M., \& Oh, C. H. 2010. Does the regional nature of multinationals affect the multinationality and performance relationship? International Business Review. 19(5), 479-488.

Rugman, A.M. and Verbeke, A. 1998a. "Corporate strategies and environmental regulations: an organizing framework”. Strategic Management Journal. 19(4): 363-75.

Rugman, A.M. and Verbeke, A. 1998b. Corporate strategy and international environmental policy. Journal of International Business Studies. 29 (4): 819-33. 
Rugman A.M., \& Verbeke, A. 1992. A note on the transnational solution and the transaction cost theory of multinational strategic management. Journal of International Business Studies. 23(4): 761-772.

Rugman, A.M. \& Verbeke, A. 2001. Subsidiary-specific advantages in multinational enterprises. Strategic Management Journal. 22(3): 237-250.

Rugman, A.M, \& Verbeke, A. 2004. A perspective on regional and global strategies of multinational enterprises. Journal of International Business Studies. 35(1):3-18

Rugman, A.M. \& Verbeke, A. 2008.A new perspective on the regional and global strategies of multinational service firms. Management International Review. 48: 397-411.

Russo, M. V., \& Fouts, P. A. 1997. A resource-based perspective on corporate environmental performance and responsibility. Academy of Management Journal. 40: 534-559.

Schot, J., \& Fischer, K. 1993. Introduction: the greening of the industrial firm. In Environmental Strategies for Industry, Fischer, K., \& Schot, J (eds). Island Press: Washington, DC: 3-33.

Scott, R., \& Meyer, J. 1994. Institutional environments and organizations: Structural complexity and individualism. Beverly Hills, CA: Sage.

Scott, W. R. 1995. Institutions and Organizations. Sage, Thousand Oaks, CA.

Sethi, S.P. \& Elango, B. 1999. The influence of ‘country of origin’ on multinational corporation global strategy: a conceptual framework. Journal of International Management. 5(4):285-298.

Sharfman M. P., Shaft T. M., Tihanyi L. 2004. A Model of the Global and Institutional Antecedents of High-level Corporate Environmental Performance. Business \& Society.43:6-36.

Sharma, S., and Vredenburg, H. 1998. Proactive corporate environmental strategy and the development of competitively valuable organizational capabilities. Strategic Management Journal. 19(8):729-753.

Shrivastava, P., \& Busch, T. 2013. Avoiding a global carbon crisis: Learning from the financial crisis. Thunderbird International Business Review. :648-658.

Stewart, R. 1993. Environmental regulation and international competitiveness. Yale Law Journal. 102: 2039-2106.

Stiglitz, J.E. 2002. Globalization and its Discontents, W.W.Norton \& Company: New York. 
Strike, V.M., Gao, J., \& Bansal, P. 2006. Being good while being bad:social responsibility and the international diversification of US firms. Journal of International Business Studies. 37:850-862.

Tansey, R., White, M., Long, R.G., \& Smith, M. A. 1996. Comparison of loglinear modeling and logistic regression in management research. Journal of Management. 22(2):339-358.

Taylor, F. 1911. Principles of scientific management. New York and London: Harper \& Brothers.

Tong, W.T., Alessandr, T.M., Reuer, J.J., and Chintakanda, A. 2008. How much does country matter? An analysis of firms' growth options. Journal of International Business Studies. 39:387-405.

Transnational Corporations, Vol 20, No. 2 August 2011, UNCTAD

http://archive.unctad.org/templates/page.asp?intItemID=2926\&lang=1

UNCTAD Report. 2011. Some reflections on climate change, green growth illusions and development space. No. 205, December 2011.

Van de Wateringen, S.L. 2005. The greening of black gold. Towards international environmental alignment in the petroleum industry. Veenendaal: Universal Press.

Van Schaik, L., \& Schunz, S. 2012. Explaining EU activism and impact in global climate politics: Is the Union a Norm - or - Interest-Driven Actor?. Journal of Common Market Studies. 50(1):169-186.

Verbeke, A. 2010. International acquisition success: Social community and dominant logic dimensions. Journal of International Business Studies, 41(1), 38.

Verrecchia RE. 1983. Discretionary disclosure. Journal of Accounting and Economics 5: 179-194.

Videras, J., \& Alberini, A. 2000. The appeal of voluntary environmental programs: which firms participate and why?. Contemporary Economic Policy. 18(4):449-461.

Waddock, S.A., \& Graves, S. B. 1997. The corporate social performance- financial performance link. Strategic Management Journal. 18(4): 303-319.

Wagner, M. 2007. On the relationship between environmental management, environmental innovation and patenting: Evidence from German manufacturing firms. Research Policy. 36(10):1587-1602.

Walls, J.L., Berrone, P., \& Phan, P.H. 2012. Corporate Governance and environmental performance: Is there really a link? Strategic Management Journal. 33(8):885-913. 
Walls J, L, Phan PH., \& Berrone P. 2011. Measuring environmental strategy: construct development, reliability and validity. Business \& Society. 50(1): 71-115.

Walls, J.L., \& Hoffman, A.J. 2013. Exceptional boards: environmental experience and positive deviance from institutional norms. Journal of Organizational Behavior.(34):253271.

Wernerfelt, B. 1984. A resource based view of the firm. Strategic Management Journal. 5: $171-180$

Wijen, F. 2014. Means versus ends in opaque institutional fields: trading off compliance and achievement in sustainability standard adoption. Academy of Management Review. 39(3): 302-323.

Whitehouse website. 2014. Accessed on May 31st 2014. http://www.whitehouse.gov/share/climate-action-plan

World Investment Report (WIR). 2010. United Nations

Xu, D., \& Shenkar, O. 2002. Institutional Distance and the Multinational Enterprise. Academy of Management Review. 27(4): 608-618.

Zaheer, S. 1997. The dynamics of the liability of foreignness: A global study of survival in financial services. Strategic Management Journal. 18(6): 439-463.

Zhou, N., \& Guillen, M. F. 2014. From Home country to Home base: A dynamic approach to the liability of foreignness. Strategic Management Journal. Published online. 
Figure 2: Industrial sectors vary in their GHG emissions

Share of total market capitalization vs. share of direct GHG emissions

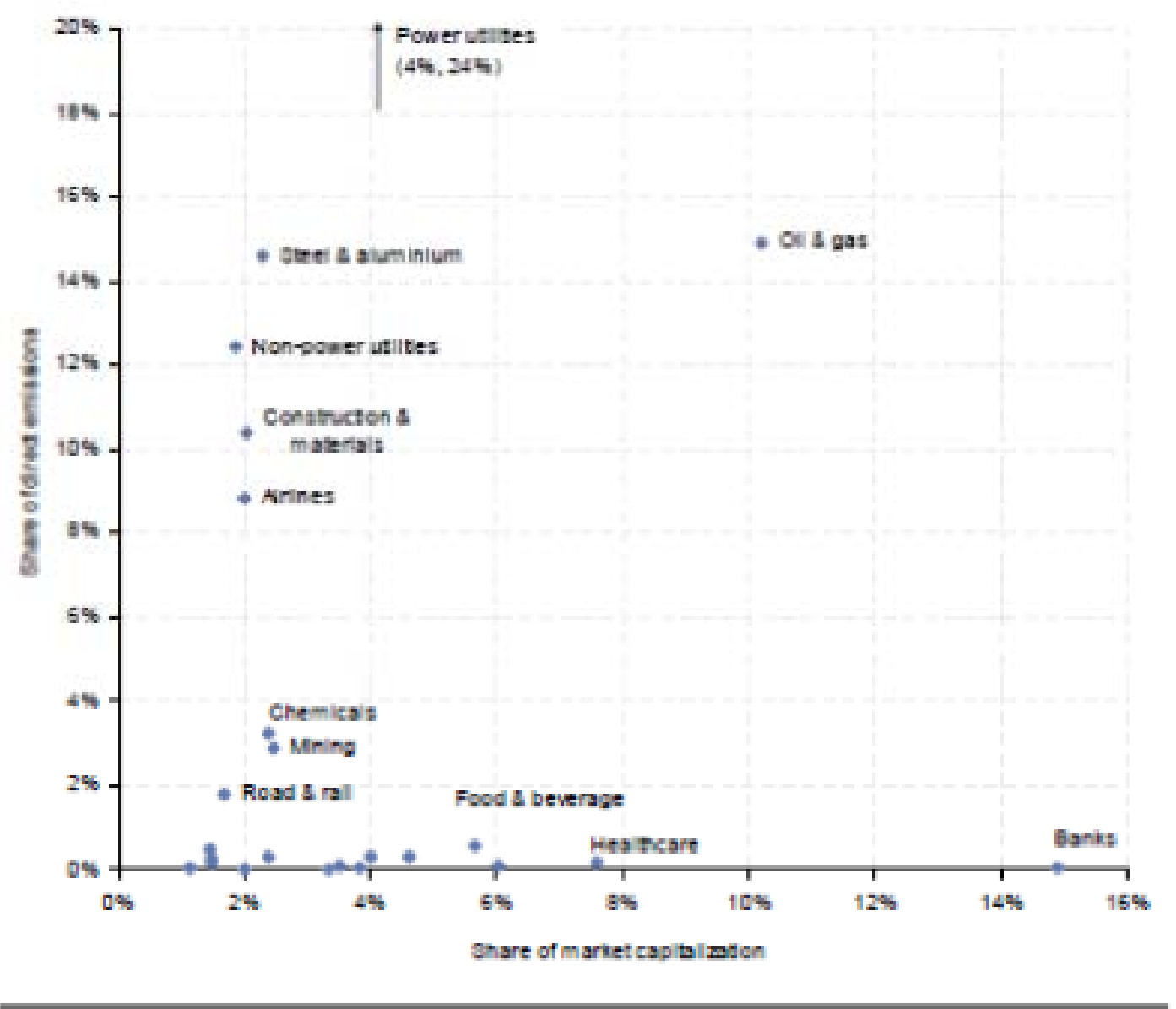

Source: Carton disclosure project, Goldman Sachs Research estimates. 
VITA

\section{SANTHOSH NARAYANAN}

1993-1998

BSc., Agriculture Science

Kerala Agricultural University

Thrissur, India

1998-2001

Master in Agricultural Economics, Kerala Agricultural University

Thrissur, India

2001-2003

Research Associate, Central Plantation Crops Research Institute

Kasaragod, India

2003-2008

Quality Manager, Kerala State Civil Supplies Corporation Ltd., Kerala, India

2008-2009

MBA

Florida International University, Miami, Florida

2009-2014

Doctoral Candidate in Business Administration

Florida International University

Miami, Florida

\section{PUBLICATIONS AND PRESENTATIONS}

Santhosh Narayanan and Sumit Kundu. 2013. Do global MNEs have better environmental performance? A study based on carbon performance. Doing well by doing Good: New perspectives on Corporate Social Responsibility and Sustainable development. Routledge (Taylor \& Francis Group). Eds. Srinivasan, V, Nagadevara, V, and Jayachandran, C.

C. Latha Bastine, Jacob Thomas, Santhosh Narayanan and N. Aswathy. 2004. Cost of production and capital productivity of coconut in Kerala, India. Journal of Plantation Crops. 32(1): 51-54. 
Santhosh Narayanan and C. Latha Bastine.2004. Price spread of coconut in the central region of Kerala. Journal of Tropical Agriculture. 42(1-2): 73-75.

Santhosh Narayanan 2013. Environmental performance: Do global and regional MNEs differ. AIB Conference 2013, Istanbul.

Santhosh Narayanan 2013. Drivers of subsidiary initiative for Base of pyramid strategy. AIB conference 2013, Istanbul.

Dina Abdel-Zaher, Santhosh Narayanan and Rimi Zakaria. 2012. What it takes to have an effective BoP strategy? An empirical examination of firm and country factors. AIB-LAT conference, Miami. April 2012. 